\title{
Process Intensification in Fuel Cell CHP Systems, the ReforCELL Project
}

\author{
José Luis Viviente ${ }^{1, *}$, Sylvie Escribano ${ }^{2}$, Giampaolo Manzolini ${ }^{3}$, Marit Stange ${ }^{4}$, \\ Carlo Tregambe ${ }^{5}$, Leonardo Roses ${ }^{6}$, Arjan J. J. Koekkoek ${ }^{7}$, Cécile Guignard ${ }^{8}$, \\ Arnaud Dauriat ${ }^{8}$ and Fausto Gallucci ${ }^{9}$ \\ 1 Funación Tecnalia Research and Innovation, Mikeletegi Pasealekua 2, 20009 Donostia-San Sebastian, Spain \\ 2 CEA/LITEN, 17 rue des Martyrs, 38054 Grenoble CEDEX 9, France; sylvie.escribano@cea.fr \\ 3 Politecnico di Milano, Deparment of Energy, via Lambruschini 4, 20156 Milano, Italy; \\ giampaolo.manzolini@polimi.it \\ 4 SINTEF, P.O. Box 124 Blindern, N-0314 Oslo, Norway; marit.stange@sintef.no \\ 5 ICI caldaie S.P.A., Via G.Pascoli 38, Zevio, 37059 Verona, Italy; carlo.tregambe@icicaldaie.com \\ 6 HyGear B.V., P.O. Box 5280, 6802 EG Arnhem, The Netherlands; leonardo.roses@hygear.nl \\ 7 Hybrid Catalysis B.V., P.O. Box 513, 5600 MB Eindhoven, The Netherlands; a.j.j.koekkoek@tue.nl \\ 8 Quantis Sàrl, EPFL Innovation Park, Bât. D, 1015 Lausanne, Switzerland; \\ cecile.guignard@quantis-intl.com (C.G.); arnaud.dauriat@quantis-intl.com (A.D.) \\ 9 Chemical Process Intensification, Department of Chemical Engineering and Chemistry, \\ Eindhoven University of Technology, P.O. Box 513, 5612 AZ Eindhoven, The Netherlands; f.gallucci@tue.nl \\ * Correspondence: joseluis.viviente@tecnalia.com; Tel.: +34-610-767-840
}

Academic Editor: Michael Henson

Received: 29 July 2016; Accepted: 1 October 2016; Published: 17 October 2016

\begin{abstract}
This paper reports the findings of a FP7/FCH JU project (ReforCELL) that developed materials (catalysts and membranes) and an advance autothermal membrane reformer for a micro Combined Heat and Power (CHP) system of $5 \mathrm{kWel}$ based on a polymer electrolyte membrane fuel cell (PEMFC). In this project, an active, stable and selective catalyst was developed for the reactions of interest and its production was scaled up to kg scale (TRL5 (TRL: Technology Readiness Level)). Simultaneously, new membranes for gas separation were developed. In particular, dense supported thin palladium-based membranes were developed for hydrogen separation from reactive mixtures. These membranes were successfully scaled up to TRL4 and used in lab-scale reactors for fluidized bed steam methane reforming (SMR) and autothermal reforming (ATR) and in a prototype reactor for ATR. Suitable sealing techniques able to integrate the different membranes in lab-scale and prototype reactors were also developed. The project also addressed the design and optimization of the subcomponents $(\mathrm{BOP})$ for the integration of the membrane reformer to the fuel cell system.
\end{abstract}

Keywords: palladium membrane; fluidized membrane reactor; hydrogen production; micro-CHP system; PEM fuel cell; ATR; SMR

\section{Introduction}

Major concerns on anthropogenic $\mathrm{CO}_{2}$ emissions and related greenhouse effect have pushed several governments to support greenhouse gas emission reduction policies. The EU, for example, set a very high target for reduction of greenhouse gas emissions by $40 \%$ compared to 1990 levels within 2030 (at least $80 \%$ by 2050 ), together with an increase by $27 \%$ of energy efficiency and renewable share in the energy consumption [1]. Stationary fuel cells offer a clean and efficient source of electricity in systems ranging from $1 \mathrm{~kW}$ up to $1 \mathrm{MW}$ or more [2]. With an appropriate fuel processing technology, fuel cells are able to tap into established or accessible sources of fuels such as natural gas but also various other fuels including biofuels and bio-gases. Combined heat and power (CHP), 
which consists of simultaneous production and use of heat and power, is certainly one of the cheapest options to increase energy efficiency with consequent primary energy savings and $\mathrm{CO}_{2}$ emission reduction [2-6]. In a distributed generation scenario, fuel cells systems lead to particularly high efficiencies (electrical efficiency up to $60 \%$, first law efficiency in cogeneration of more than $90 \%$ ), thereby attaining considerable primary energy saving whilst avoiding transmission losses. When using natural gas (thereby building on existing infrastructure), stationary fuel cells can substantially reduce $\mathrm{CO}_{2}$ emissions as a highly efficient conversion of low-carbon natural gas replaces the central supply from a still predominantly fossil-fuels based electricity mix. Depending on the fuel used and its fuel, the technology can potentially eliminate $\mathrm{CO}_{2}$ and other emissions altogether [2].

In addition, the better fuel exploitation of the CHP systems compared to conventional generation systems (i.e., power plants and boilers) allows economic savings which can cover the additional investment costs. Among CHP systems, micro-cogeneration systems (cogeneration unit with a maximum capacity below $50 \mathrm{kWe} ;(2004 / 8 / \mathrm{EC}))$ are a very interesting option because of the significant share of the overall primary energy consumptions (about 30\%) of residential applications $[7,8]$. Moreover, with its flexible modulation capabilities and high efficiencies at partial loads, the technology shows strong potential for grid balancing in the context of a power mix with more intermittent renewables and electric heating solutions like heat pumps [2,9].

In this work, an overview of the main results of the ReforCELL project is presented. The aim of the ReforCELL project was to develop a highly efficient polymer electrolyte membrane (PEM) fuel cell micro Combined Heat and Power cogeneration system (net energy efficiency $>42 \%$ and overall efficiency $>90 \%$ ) based on a novel, more efficient and cheaper hydrogen reformer production unit together with the new design of the subcomponent for the BoP. This new high efficiency PEM fuel cell $\mathrm{m}-\mathrm{CHP}$ system is based on the design, construction and testing of an advanced membrane reactor for pure hydrogen production $\left(5 \mathrm{Nm}^{3} / \mathrm{h}\right)$ from reforming. In addition, the design and optimization of the subcomponents $(\mathrm{BoP})$ for the integration of the membrane reformer to the fuel cell system were also addressed.

The main idea of ReforCELL was to apply the concept of process intensification [10] in the production of hydrogen feeding the Fuel Cell. The technology of membrane reactors was developed in the last decades and it has demonstrated a high degree of process intensification where the combination of a membrane based separation and a catalytic chemical reaction in one unit take place [11-18]. In equilibrium limited reaction systems, such as in fuel reforming or dehydrogenations, the selective separation of a product of the reaction (i.e., $\mathrm{H}_{2}$ ), implies a displacement of the thermodynamic equilibrium towards the products, thus achieving higher fuel conversions and direct product separation (a separation unit downstream is not required) [19].

The traditional reformers include several steps for producing $\mathrm{H}_{2}$ with adequate quality to feed the fuel cell stack (Figure 1) [8,20-25]. Two commercial technologies based on a steam-methane reforming reactor (Figure 1) and on an autothermal reformer (ATR) were modelled to assess the performance of reference technologies. The main indexes of the two reference cases are summarized in Table 1. Results are consistent with available information of commercial systems based on this technology [26-29].

Table 1. Performances of reference case.

\begin{tabular}{ccc}
\hline Result & SMR & ATR \\
\hline Net electric efficiency (\%LHV) & $34.2 \%$ & $32.3 \%$ \\
Net thermal efficiency (\%LHV) & $46.3 \%$ & $50.5 \%$ \\
Overall efficiency (\%LHV) & $80.5 \%$ & $82.8 \%$ \\
Second law efficiency (\%Ex) & $37.59 \%$ & $36.21 \%$ \\
Fuel Cell single cell voltage (V) & 0.740 & 0.728 \\
\hline
\end{tabular}




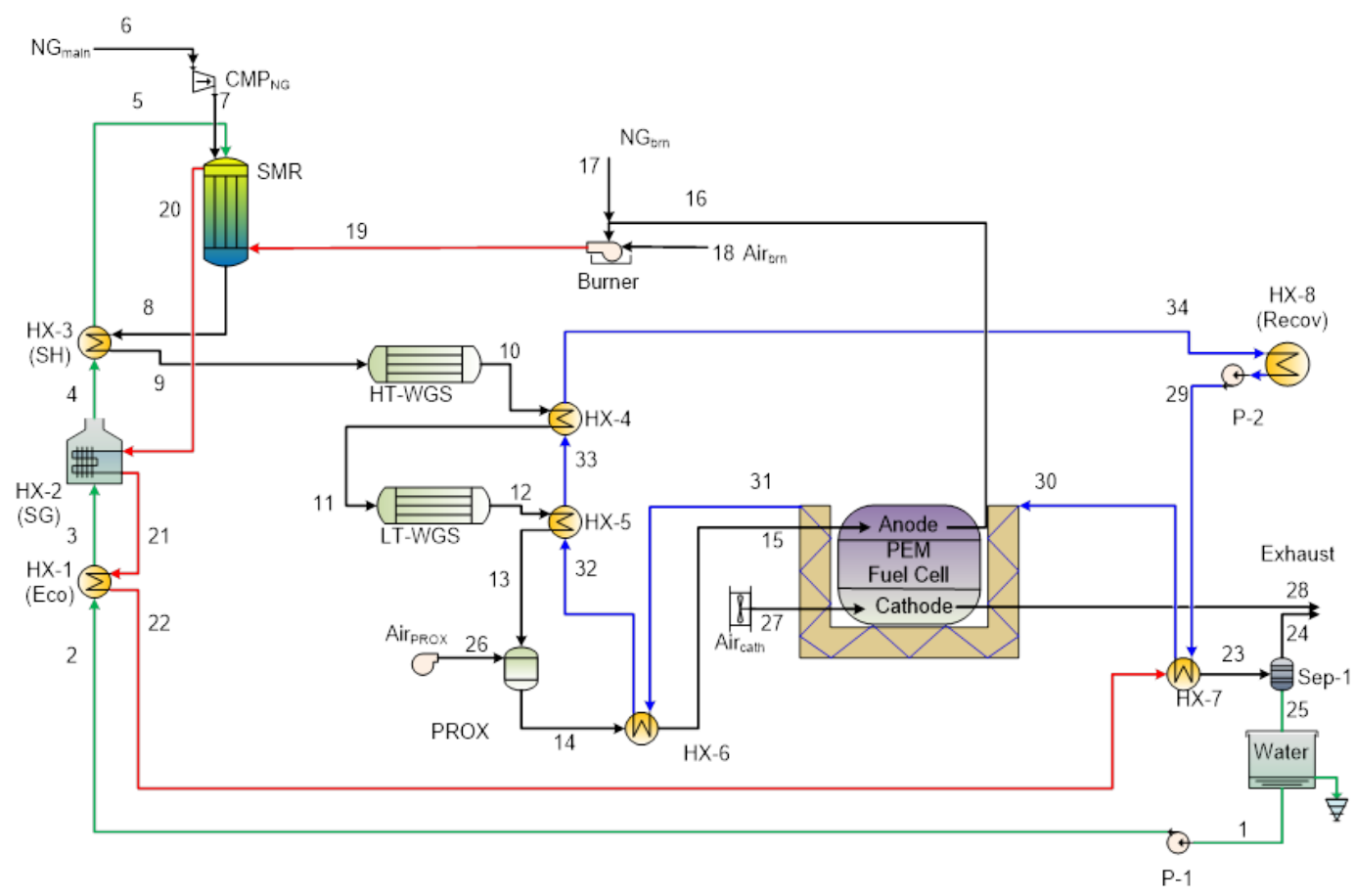

Figure 1. Layout of PEM m-CHP unit using traditional reforming (TR) for fuel processing.

The new concept addressed in ReforCELL reduces the system complexity thanks to the simultaneous hydrogen conversion and separation in one step (Membrane Reactor, Figure 2) [26,30] with expected thermodynamic advantages (net electric efficiency above $40 \%$ ) and reduction of the reforming temperature. In addition, there is a cost reduction of the other components in the reformer (e.g., heat exchangers) and in the BoP (auxiliary elements) when integrating the membrane reformer to the fuel cell and building up the m-CHP system [4].

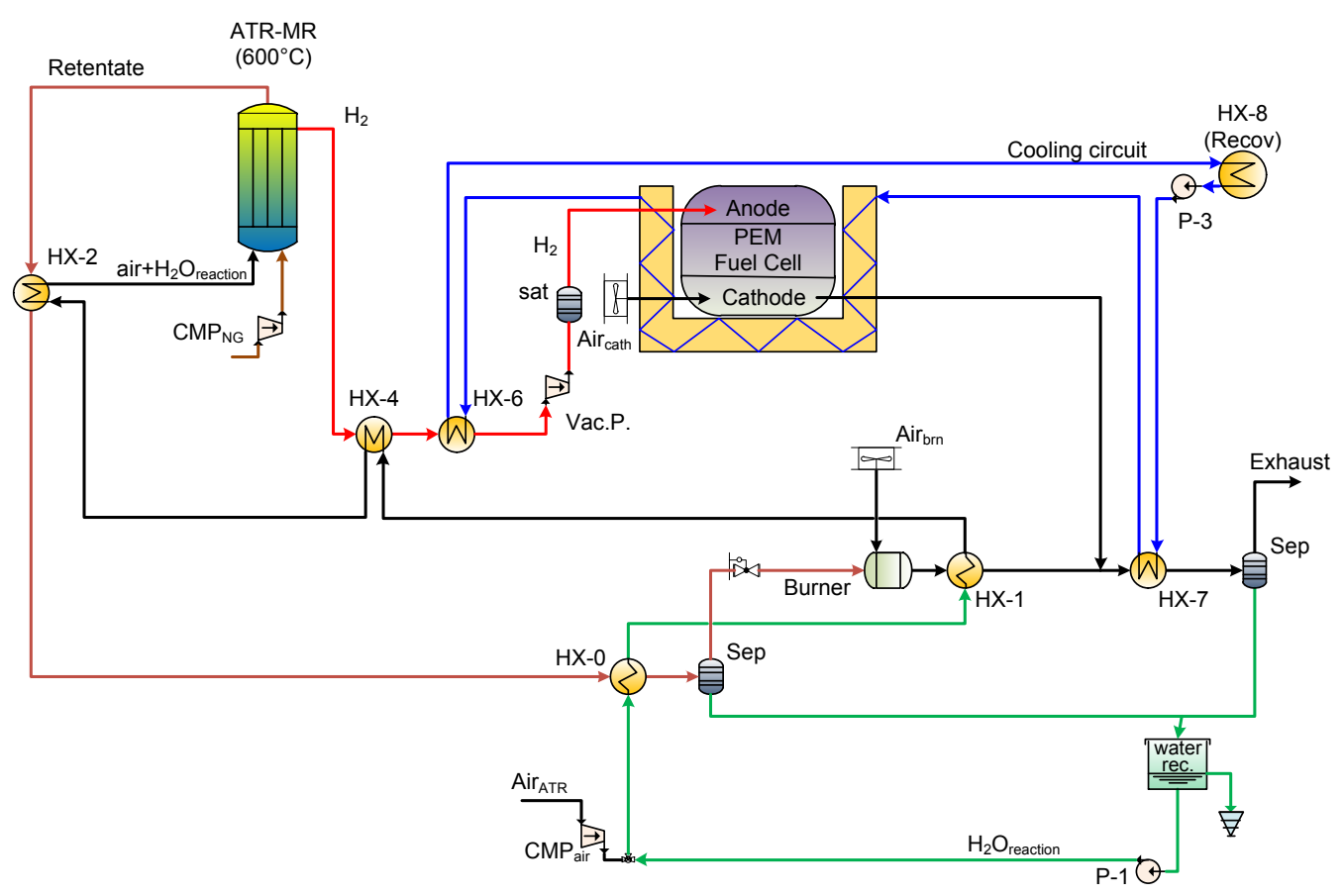

Figure 2. Layout of PEM m-CHP unit using membrane reformer (MR) for fuel processing. Reproduced with permission from [26], Copyright, 2015, Elsevier. 
The ReforCELL work plan consisted on activities related to the whole product chain: i.e., development of materials/components (catalysts, membranes, supports, sealings, etc.) through integration/validation at lab-scale, until development/validation of pilot scale Autothermal membrane reformer (ATR-MR) and the proof of concept/validation of the new PEM fuel cell m-CHP system. Additionally, assessment of environmental, health and safety issues-in relation to the new intensified chemical processes and $\mathrm{m}-\mathrm{CHP}$ - was also carried out thanks to a screening life cycle analysis considering all components and steps involved to build the system.

For a maximum impact on the European industry, this research was carried out covering the complete value chain of micro-CHP fuel cell systems. It gathered together a multidisciplinary and complementary team having the right expertise, including top level European Research Institutes and Universities (6 RES) working together with representative top industries (4 SME and 1 IND) in different sectors (from materials to micro-CHP systems developers).

The ReforCELL Project was funded under the FP7 for the Fuel Cell and Hydrogen Joint Undertaking. The Project started the 1st of February 2012 and it has run for 47 months. In the following, the main results in terms of catalysts, membranes and membrane reactors are highlighted.

\section{Experimental Section}

\subsection{Catalyst}

The high reaction temperatures associated with Autothermal Reforming (ATR) requires the use of catalysts with extreme thermal stability and high catalytic activity. These requirements put strenuous demands on the catalyst material in their agglomeration and vaporization resistance and structural/morphological stability. The carbon formation and deactivation by sulphur are also key challenges for ATR catalysts. For clean gas the main risk in reforming reactions is the formation of carbon. This has to be avoided since the formation of carbon may rapidly reduce the activity of the catalyst $[31,32]$.

At present, the state-of-the-art ATR catalysts consist of the following materials: Ni catalysts on thermally stable supports, group VIII noble metals ( $\mathrm{Pt}, \mathrm{Ru}$, and $\mathrm{Rh}$ ) supported onto various high surface area oxide substrates, catalysts with a perovskite structure $\mathrm{ABO}_{3}$ [33-36], carbides of group VI metals [37,38], (noble) metal substituted pyrochlores $\mathrm{A}_{2} \mathrm{~B}_{2} \mathrm{O}_{7}[39,40]$, and alumina supported catalysts containing nickel and uranium oxides (developed at BIC), with high activity and stability and a decrease in coke formation [41-43]. Commercial catalysts for both authotermal reforming (ATR) and steam methane reforming (SMR) are based on nickel with differences on the support.

The integration of the membrane reactor in the reforming system for hydrogen separation will allow a higher hydrogen yield at much lower temperatures than in the benchmark ATR and SMR technologies. However, the feasibility of such integration requires the development of innovative ATR catalysts with improved catalytic activity and high resistance to carbon formation. Catalyst poisoning by sulphur was not addressed because a desulphurisation unit was considered on the feed line. The deactivation of the catalyst by carbon formation is a structure sensitive reaction. Specifically, the deactivation mechanism is influenced by the cluster size of the active metal, where the larger metal clusters show a much stronger interaction with carbon than smaller, well-dispersed, metal particles [44,45]. Based on this fact, the control of the electronic structure and size of the active metal surfaces has been the strategy followed in the development of innovative ATR catalysts with improved catalytic activity and stability. The reforming catalyst developed was designed based on conventional supported catalysts. The optimal selection of the catalyst was performed by carrying out ATR and SMR studies varying the composition of the active phase $(\mathrm{Ni}, \mathrm{Ru}, \mathrm{Rh}, \mathrm{Pt})$, the support $\left(\alpha-\mathrm{Al}_{2} \mathrm{O}_{3}, \gamma-\mathrm{Al}_{2} \mathrm{O}_{3}\right.$, $\mathrm{MgAlO}_{2}, \mathrm{SiO}_{2}, \mathrm{CeO}_{2} ; \mathrm{CeO}_{2}-\mathrm{ZrO}_{2}$ ), and the method of preparation (impregnation, co-precipitation, etc.). Of particular interest are the $\mathrm{CeO}_{2}$ and $\mathrm{CeO}_{2}-\mathrm{ZrO}_{2}$ based supports, as these are known to greatly improve catalytic performance due to support metal interaction and oxygen storage capabilities [46,47]. As a comparison with the new catalyst, several commercial catalysts were characterized as well. 
The elemental analysis of the catalyst was done by ICP-OES technique. The loss of material from the samples was measured by gravimetry before and after a thermal treatment at $900{ }^{\circ} \mathrm{C}$. The textural properties of the supported catalyst (i.e., pore size distribution, surface area) were determined by physisorption analysis (BET) in a Micromeritics ASAP 2020 instrument. X-ray Diffraction analysis (Bruker D8 Advance equipment) was used to determine the crystalline structure and crystalline sizes. Finally, transmission electron microscopy (TEM) analysis (FEI Tecnai F30) was used for a deeper study of the morphology, size, and distribution of the catalyst particles onto the supports as well as of the support. Both fresh and used samples were characterized.

The optimization of the selected catalyst was done by catalytic screening in the ATR and SMR reaction of methane in a $8 \mathrm{~mm}$ i.d. quartz fixed-bed reactor. A feed composition of Ar: $\mathrm{CH}_{4}: \mathrm{H}_{2} \mathrm{O}: \mathrm{O}_{2}$ equal to 80:5:15:0/75:5:15:5 in SMR and to 30:15:50:5 in ATR was used. The tests were carried out under atmospheric pressure and temperatures ranging from 500 to $600{ }^{\circ} \mathrm{C}$ and inlet gas flow rate to obtain a Gas Hourly Space Velocity (GHSV) of 15,000 $\mathrm{h}^{-1}$. Afterward, carbonaceous deposits on the catalyst were tested using Temperature Programmed Oxidation (TPO). In order to obtain the desired properties of the catalyst support, a deep characterization of fresh and used samples of all catalytic series prepared was performed. The main structural and surface characteristics of the catalysts that have a strong influence on the ATR/SMR catalytic activity and stability were identified. From catalytic screening tests, durability tests and characterization of ATR/SMR catalysts, the optimal composition and preparation method of catalyst was selected, which is based on Ru catalysts deposited on optimized $\mathrm{Zr}$ /Ce-oxide based support.

The catalyst preparation was optimized for production on a kilogram scale using a $10 \mathrm{~L}$ batch reactor (Figure 3), and a $0.5 \mathrm{~kg}$ batch of the catalyst having a particle size of $125-250 \mu \mathrm{m}$ was prepared.
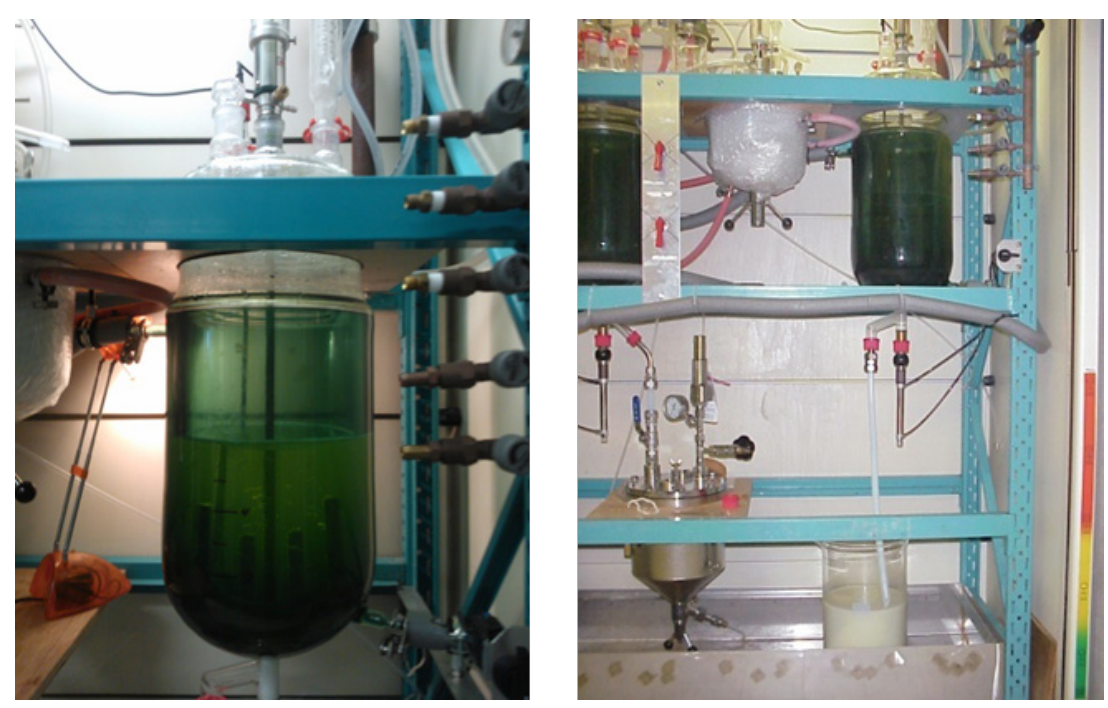

Figure 3. A $10 \mathrm{~L}$ double walled glass reactor used for support synthesis and loading of the ruthenium onto the support.

\subsection{Membranes}

Much effort has been put into the development of $\mathrm{Pd}$-based membranes for selective $\mathrm{H}_{2}$ separation in the literature in order to overcome the barrier towards large-scale industrial applications [11,12]. In general, membrane stability over a long period of time with sufficient perm-selectivity is the key parameter which would make these membranes interesting for the industrial scale. The selection of the proper support where Pd-layers are deposited becomes important in order to achieve this goal. Asymmetric porous ceramic supports have good surface quality suitable for the preparation of very thin $(<5 \mu \mathrm{m})$ Pd-based membranes. Surface roughness and the presence of large pores inhibit the deposition of thin palladium layers. Another important issue to be considered is the strong interaction between 
the Pd membrane and the support. At high temperatures $\left(>600^{\circ} \mathrm{C}\right)$ alumina supports react with $\mathrm{Pd}$ forming Pd-Al alloy with low hydrogen permeation [48]. However, zirconia and yttria-stabilized zirconia (YSZ) are stable at $650{ }^{\circ} \mathrm{C}[49,50]$. On the other hand, porous metallic supports have high mechanical strength, offer good thermal shock resistance and their thermal expansion coefficient is similar to that of Pd. However, they can diffuse at high temperatures forming an alloy with Pd and losing hydrogen permeation properties. The inter-metallic diffusion can be avoided by deposition of an inter-metallic diffusion barrier layer (IMDBL) onto the metallic support such as inorganic porous alumina or zirconia layers [11].

Generally, ceramic supports show improved $\mathrm{H}_{2}$ diffusion through the support, thus enhancing permeations through the membranes [51]. However, the mechanical strength of these supports is much lower compared to porous metallic supports. Therefore, thicker ceramic supports are needed. Overall, the use of ceramic supports implies that less surface area is needed in order to achieve high $\mathrm{H}_{2}$ fluxes. On the other side, metallic supported membranes have shown very good stabilities over time with outstanding selectivities [52,53]. Nevertheless, the permeance values measured are 3-4 times lower than ceramic supported membranes when membranes are developed by direct electroless plating (ELP) deposition [51,52], thus a longer membrane area should be prepared in order to achieve the desired target of $\mathrm{H}_{2}$ permeation with the corresponding economical penalty for the process. As it can be concluded, there is not yet an ideal membrane for $\mathrm{H}_{2}$ separation and a compromise between durability and functionality should still be achieved. Both metallic and ceramic supported Pd-membranes have been used in the literature in fixed bed and fluidized bed configurations showing high resistances to erosion. Therefore, the stability under reacting conditions was also assessed. Finally, another challenging issue regarding the ceramic supported membranes is the sealing between the ceramic tubes and metallic tubes for the coupling in the membrane reactor.

Three different types of membranes were developed for the lab-scale reactors in the frame of ReforCELL: Pd-based tubular ceramic supported membranes (Figure 4), Pd-based tubular metallic supported membranes (Figure 5), and Pd-based micro-channel supported membranes (Figure 6). $\mathrm{Pd}$-based selective layers onto tubular supports were developed by direct simultaneous $\mathrm{Pd}$ and $\mathrm{Ag}$ electroless plating deposition [51-54] in a one step process. Pd membranes for the micro-channel supported membranes were developed using a two-step process $[55,56]$ where the defect free Pd-alloy film is first prepared by sputtering deposition onto the extremely smooth surface of a silicon wafer. In a second step the film is removed from the wafer and integrated in a module with micro-channels ( 25 channels of $25 \times 1 \times 1 \mathrm{~mm}$ size) on the feed side and either micro-channels or a porous stainless steel support on the permeate side [57].

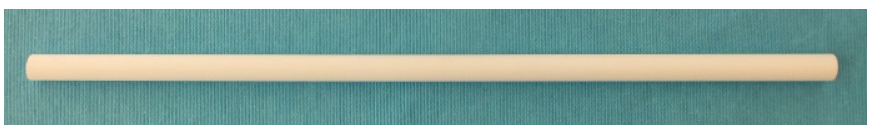

(a)

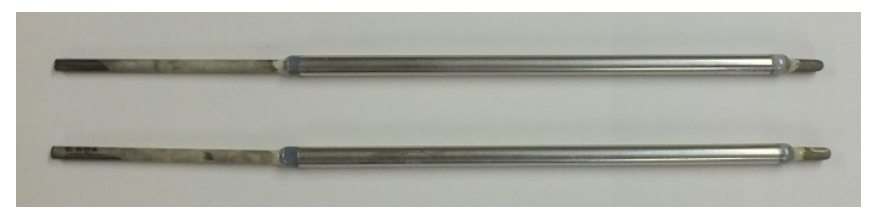

(b)

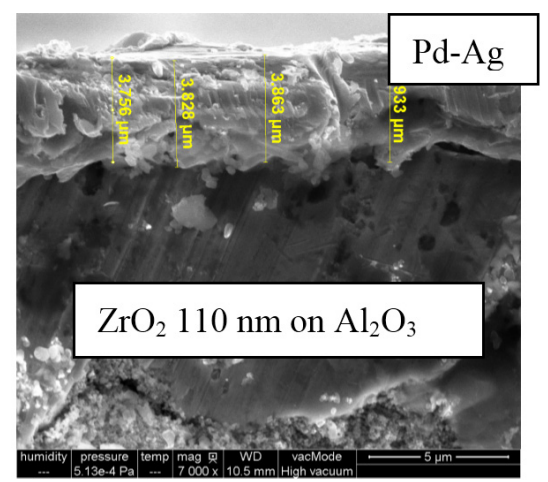

(c)

Figure 4. Pd-based tubular ceramic supported membranes: (a) Ceramic porous support ( $\mathrm{ZrO} 2(110 \mathrm{~nm}$ pore size)- $\mathrm{Al}_{2} \mathrm{O}_{3}$ tube from Rauschert Kloster Veilsdorf)); (b) Pd-Ag membranes and (c) Cross-section SEM image of a $\sim 4$ microns thick PdeAg membrane supported on ceramic porous tube. Reproduced with permission from [51] Copyright, 2015, Elsevier. 


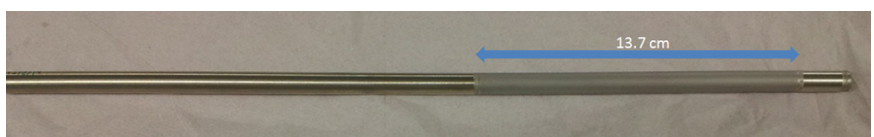

(a)

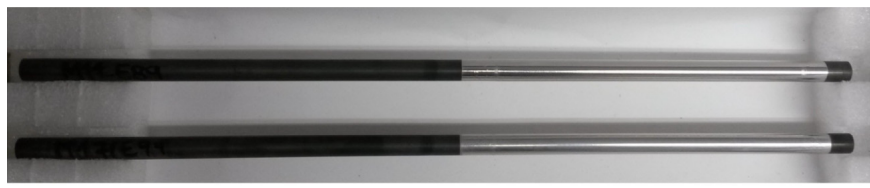

(b)

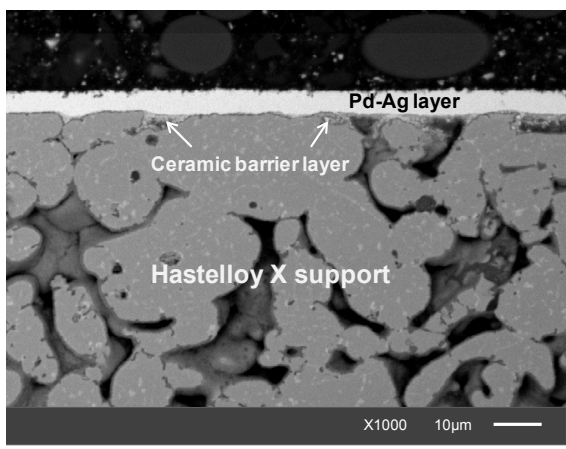

(c)

Figure 5. Pd-based tubular metallic supported membranes: (a) Metal porous support (Hastealloy X from Mott Corp); (b) Pd-Ag membranes and (c) Cross-section SEM image of a $\sim 5$ microns thick PdeAg membrane supported on ceramic coated Hastelloy $X$ porous tube. Reproduced with permission from [52] Copyright, 2015, Elsevier.

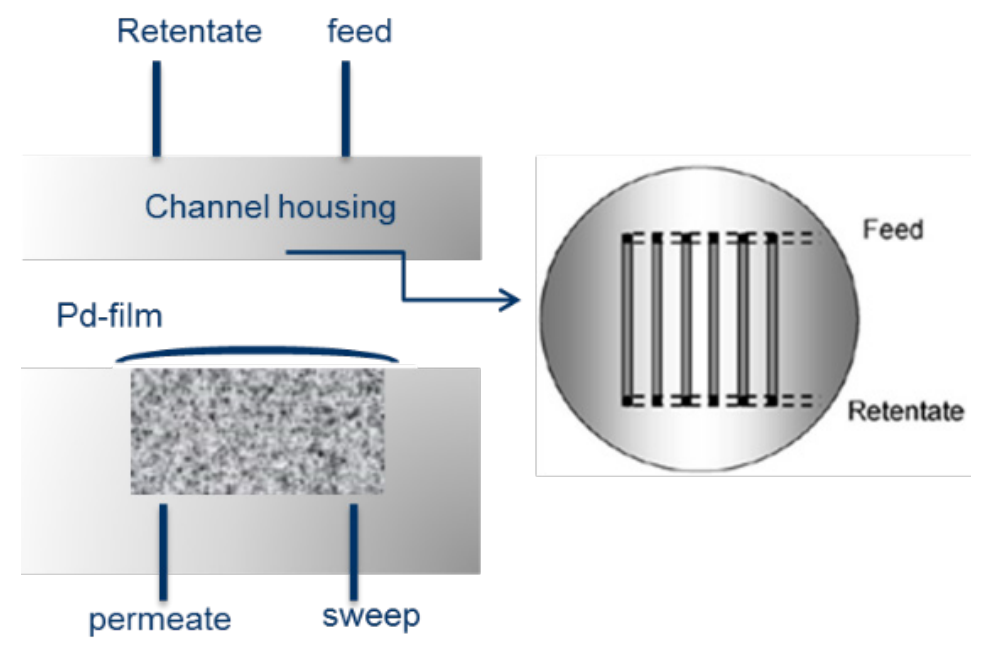

Figure 6. Pd-based micro-channel module where a thin Pd-based film is placed between the feed and permeate section.

Single gas permeation tests of the $\mathrm{Pd}-\mathrm{Ag}$ ceramic supported membranes showed $\mathrm{H}_{2}$ permeances $\left(3.8 \times 10^{-6} \mathrm{~mol} \cdot \mathrm{m}^{-2} \cdot \mathrm{s}^{-1} \cdot \mathrm{Pa}^{-1}\right.$ at $400{ }^{\circ} \mathrm{C} ; 5.2 \times 10^{-6} \mathrm{~mol} \cdot \mathrm{m}^{-2} \cdot \mathrm{s}^{-1} \cdot \mathrm{Pa}^{-1}$ at $\left.600{ }^{\circ} \mathrm{C}\right)$ and ideal perm-selectivities $\left(\mathrm{H}_{2} / \mathrm{N}_{2}>10,000\right)$ well above the targets of the project. On the other side, permeation tests of $\mathrm{Pd}-\mathrm{Ag}$ metallic supported membranes showed $\mathrm{H}_{2}$ permeances of $1 \times 10^{-6} \mathrm{~mol} \cdot \mathrm{m}^{-2} \cdot \mathrm{s}^{-1} \cdot \mathrm{Pa}^{-1}$ and ideal perm-selectivities $\mathrm{H}_{2} / \mathrm{N}_{2}$ higher than 200,000. Detailed information and characterization of these membranes can be found in the work of Fernandez et al. [51,52] and Medrano et al. [53].

Table 2 lists commercially available membranes and most promising thin Pd-based membranes (with high $\mathrm{H}_{2}$ permeation) reported in the literature. The $\mathrm{Pd}-\mathrm{Ag}$ ceramic supported membranes developed in the present work show one of the best combinations between high permeation and high ideal perm-selectivities $\left(\mathrm{H}_{2} / \mathrm{N}_{2}\right)$. It also shows that Pd-based metallic membranes have the highest selectivity but the $\mathrm{H}_{2}$ permeance is lower than for the ceramic supported membranes.

Following the validation of the lab-scale reactor, 34 membranes of 22-23 cm long (OD $10 \mathrm{~mm}$-ID $7 \mathrm{~mm}$ ) were delivered for the reformer prototype (Figure 7). 
Table 2. Comparison of different commercial and Pd based membranes reported in the literature.

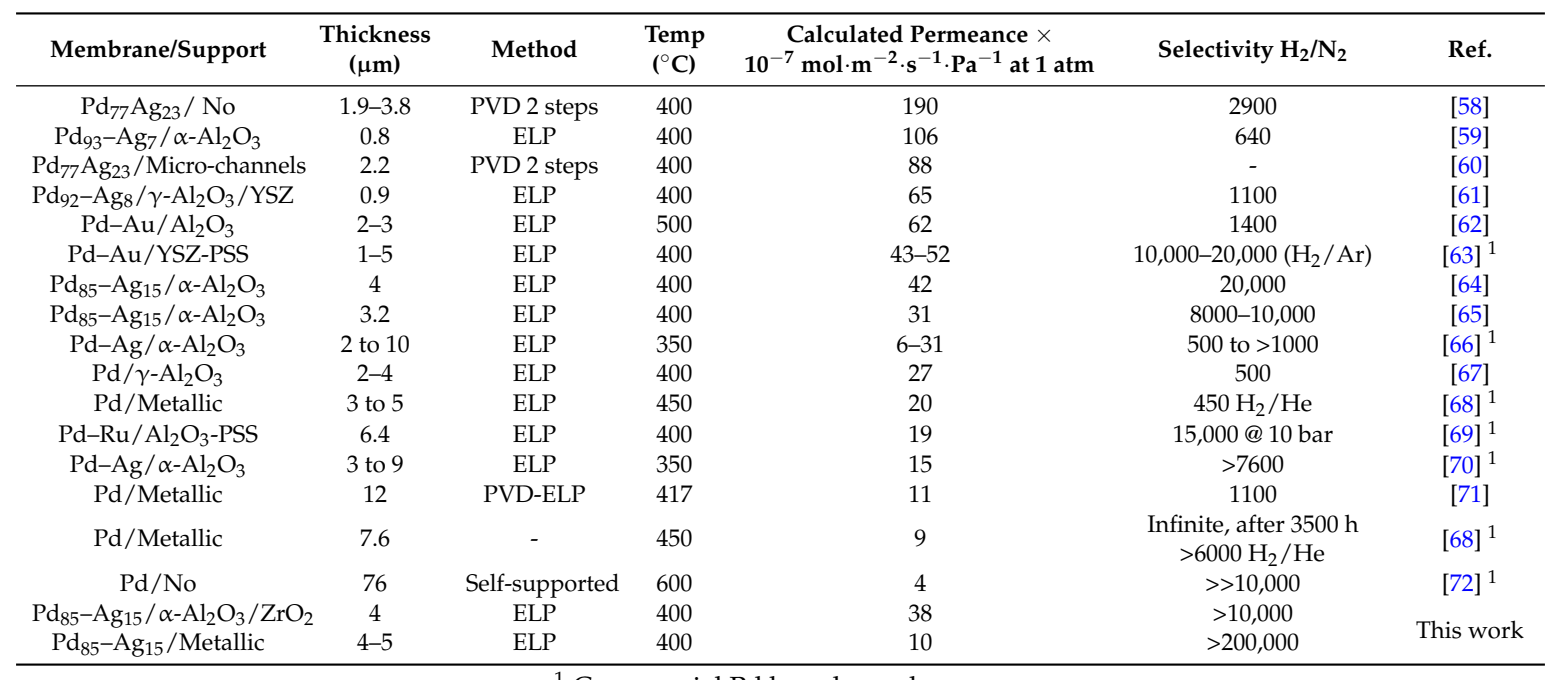

${ }^{1}$ Commercial Pd based membranes.

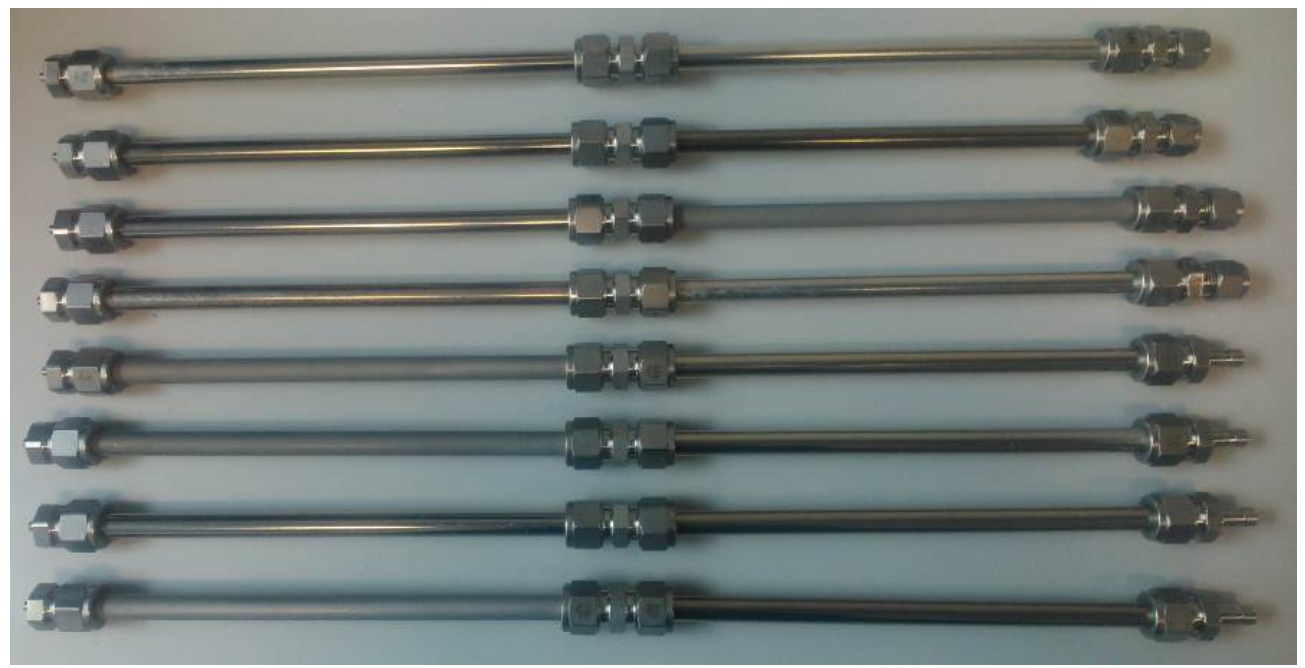

Figure 7. Layout of the $\mathrm{Pd}-\mathrm{Ag}$ membranes to be integrated in the reactor prototype.

\subsection{Lab Scale Reactors}

Once the catalysts and membranes were developed showing promising results, both were combined in modules for lab scale testing under reacting conditions for all processes investigated in the ReforCELL project. In this section the setups constructed to achieve this objective are presented.

Two different lab-scale reactor configurations were selected for the lab scale demonstration of the reforming reaction in the membrane reactor. The first configuration is the micro-channel membrane reactor that reduces gas phase diffusion limitations and that increases the membrane area to the reactor-to-volume ratio compared to traditional tubular reactors. The second configuration is the fluidized bed membrane reactor, where the developed membranes should withstand erosion form particles.

In the micro-channel reactor setup, a packed bed of catalyst (either a commercial JM HiFuel or a $\mathrm{Ru} / \mathrm{Ce}_{0.75} \mathrm{Zr}_{0.25} \mathrm{O}_{2}$ catalyst developed in ReforCELL with sieve fraction 125-250 $\mu \mathrm{m}$ ) was applied into the feed side channels of the microchannel system (Figure 6). The amount of catalyst loaded in 25 channels of $25 \times 1 \times 1 \mathrm{~mm}$ was $\sim 1.1 \mathrm{~g}$ for the JM HiFuel catalyst and $\sim 1.8 \mathrm{~g}$ for the $\mathrm{Ru} / \mathrm{Ce}_{0.75} \mathrm{Zr}_{0.25} \mathrm{O}_{2}$. The thickness of the Pd-alloy membrane integrated in the micro-channel reactor is $\sim 10 \mu \mathrm{m}$. The stability and performance under varying SMR conditions at temperatures between 400 and $550{ }^{\circ} \mathrm{C}$, pressures 
up to 8 bars and varying space velocities and feed composition, is investigated over periods of up to 75 days. $\mathrm{CH}_{4}(99.95 \%)$ and $\mathrm{H}_{2} \mathrm{O}$ (Millipore, Amsterdam, Netherlands) were introduced at the feed side (after flushing with $\mathrm{N}_{2}$ ). The $\mathrm{H}_{2}$ flux was calculated from the measured hydrogen concentration in the permeate using a calibrated flow of Ar as sweep gas. The test setup used for the experiments was described in more detail previously [57].

The fluidized bed membrane reactor setup was designed and built for hosting Pd-based membranes produced in the ReforCELL project as well as commercial ones. The equipment can be used for testing the permeation properties of the membranes using single gases, simulated mixtures of gases, and also in reactive conditions with fluidized catalyst (Steam or Autothermal reforming (SMR/ATR) and Water Gas Shift (WGS) reaction). The reactor diameter and height are $0.10 \mathrm{~m}$ and $0.62 \mathrm{~m}$ respectively, where the distance between the bottom of the vertically inserted membranes to the bottom plate distributor was $0.08 \mathrm{~m}$. This distance is enough to allow fast methane (partial) oxidation such that the heat for reforming is generated below the membranes and the oxygen is completely used and no oxidation of the membrane would occur. The maximum operating temperature is $600{ }^{\circ} \mathrm{C}$. The feed flow rate is controlled by digital mass flow controllers and the steam flow by a CEM (Controlled Evaporator and Mixer) system (Bronkhorst, Ruurlo, Netherlands). The pressure in the reactor was controlled with a back-pressure regulator after steam condensation and knock-out. The flow rates of the permeate and retentate were monitored by Brooks mass flow meters. Two separate SICK in line analysers were used to monitor the gas composition continuously of both the permeate and retentate streams. To determine the $\mathrm{N}_{2}$ leakage the same HORIBA film flow meter was used as in the membrane characterization setup. To enhance the driving force for hydrogen permeation the test setup is equipped with a vacuum pump for hydrogen (ATEX certified). The process flow diagram (PFD) for the Reforming Test Setup is given in Figure 8.

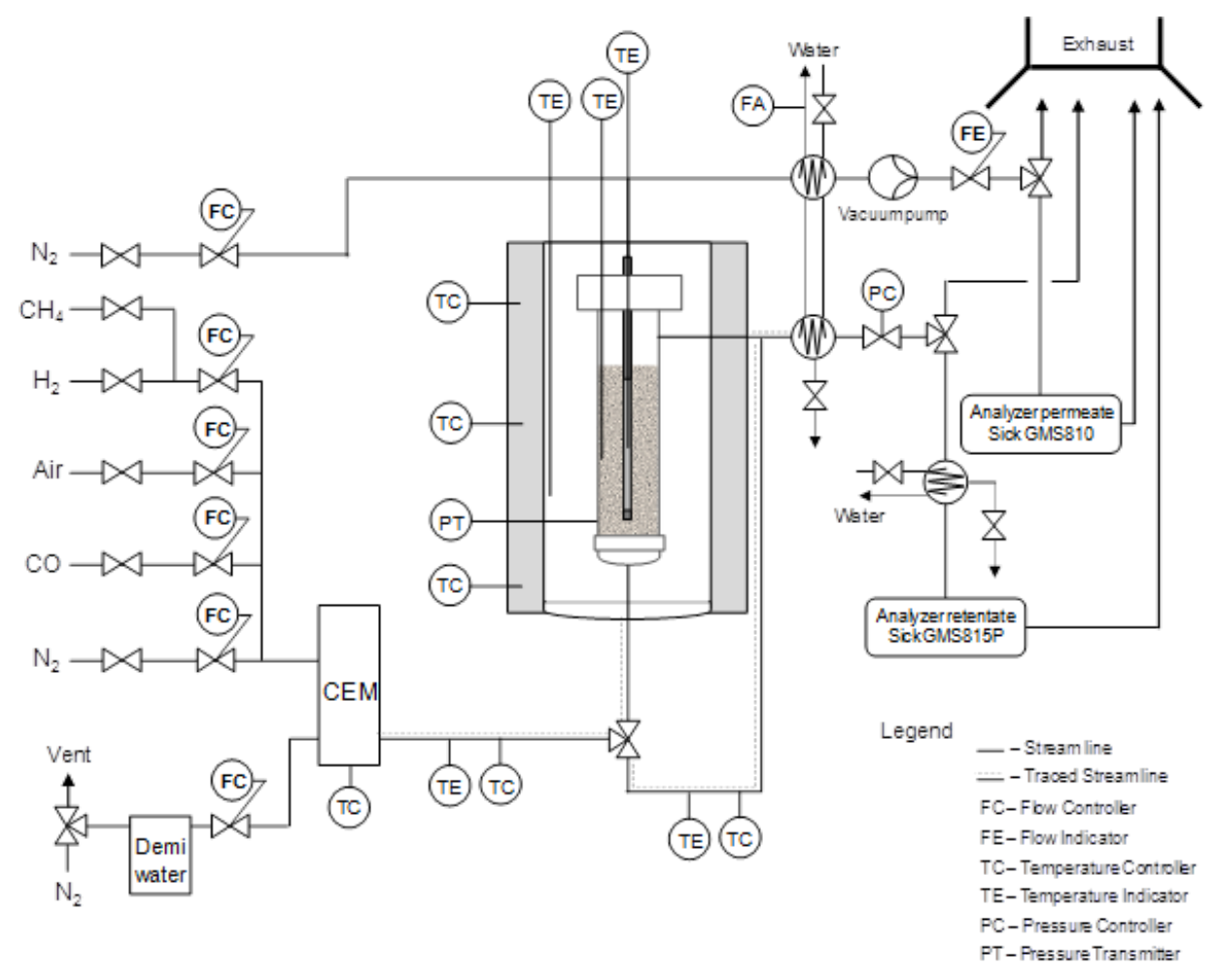

Figure 8. PFD of the fluidized bed membrane reactor used for the ATR/SMR lab scale demonstration. Reproduced with permission from [51] Copyright, 2015, Elsevier.

A $\mathrm{Ru} / \mathrm{Ce}_{0.75} \mathrm{Zr}_{0.25} \mathrm{O}_{2}$ catalyst (average sieve fraction 125-250 $\mu \mathrm{m}$ with a bulk density of $2100-2300 \mathrm{~kg} / \mathrm{m}^{3}$ ) together with $\mathrm{ZrO}_{2}$ filler material (average sieved fraction of $260 \mu \mathrm{m}$, bulk density 
of $2100-2300 \mathrm{~kg} / \mu \mathrm{m}$ ) developed in the frame of the project was used in this study. From separate attrition tests it was found that the catalyst is not damaged when used in fluidization conditions: the particle size distribution does not change after $24 \mathrm{~h}$ of fluidization (tested at low and high temperature).

The tests with autothermal reforming and steam reforming of methane were carried out with different molar feed ratios of $\mathrm{CH}_{4} / \mathrm{H}_{2} \mathrm{O} / \mathrm{O}_{2} / \mathrm{N}_{2}$. The volumetric flow rate was selected to ensure proper fluidization throughout the reactor $\left(u / u_{m f}>1.3\right)$. The experimental results were also compared to the results with commercial membranes, where the flow rates were changed to maintain the same fluidization regime around the membranes (as the different membranes occupy a different cross section of the reactor).

\subsection{ATR Prototype}

The ATR pilot reactor was designed for operating at 8 bar $_{\mathrm{a}}$ at $600{ }^{\circ} \mathrm{C}$ with a maximum hydrogen production capacity of $5 \mathrm{Nm}^{3} / \mathrm{h}$ and capable to modulate to a minimum output of $1.5 \mathrm{Nm}^{3} / \mathrm{h}$ of hydrogen. The reaction section includes an array of thermocouples giving information about the axial and radial distribution of the temperatures inside the reactor. The prototype consisted of a fluidized bed membrane reactor with $30 \mathrm{Pd}$-based ceramic supported membranes of $22-23 \mathrm{~cm}$ long (OD $10 \mathrm{~mm}-\mathrm{ID} 7 \mathrm{~mm}$ ) prepared by electroless plating and assembled two by two (Figure 7).

The novel fuel processor module was built using the membrane reactor with all needed balance of plant mounted into a skid for ease of transportation (Figure 9). The fuel processor is completely automated and controlled by a smart controller. The system allows for remote monitoring and control by a separate computer.

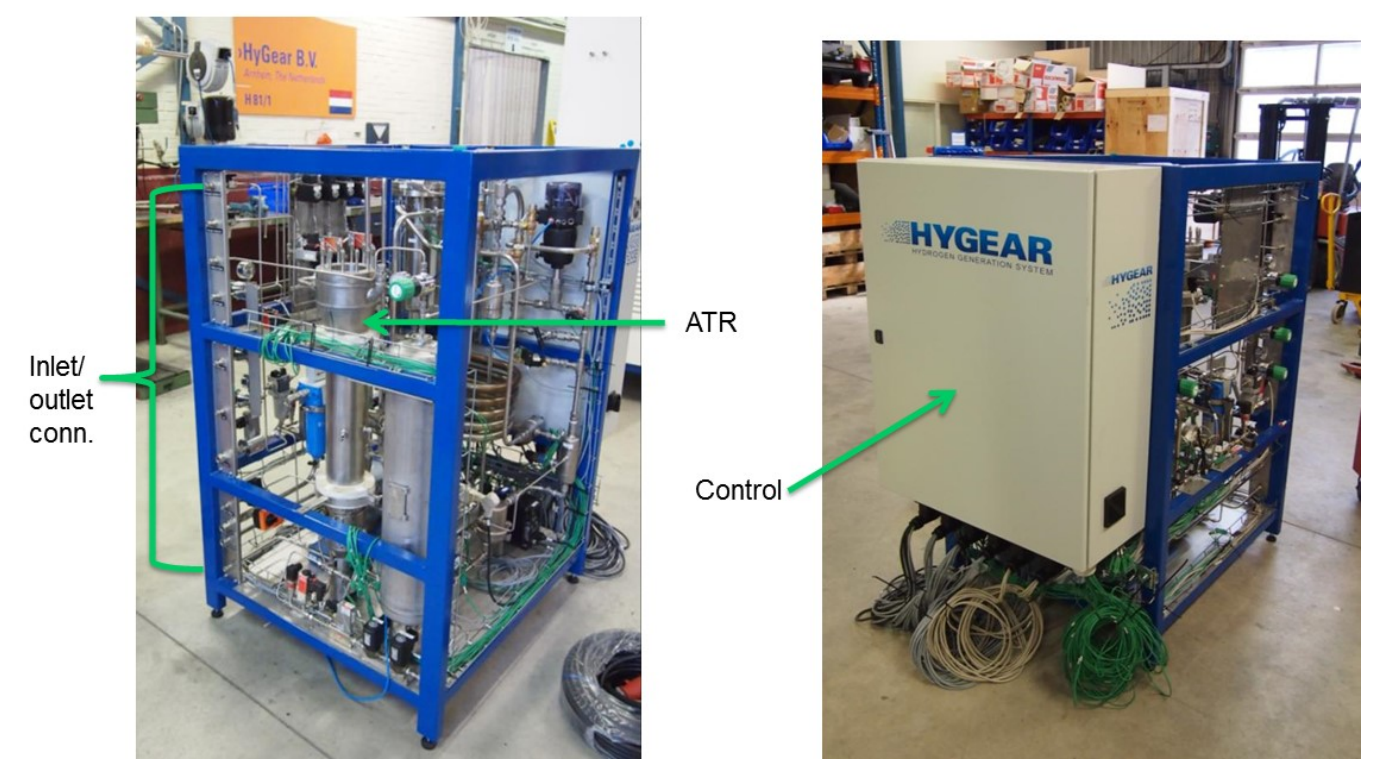

Figure 9. Picture of the prototype reactor for ATR process.

\subsection{Fuel Cell Stack}

Along with the reformer and Balance of Plant (BoP), one main component of the m-CHP system is the Fuel Cell Stack. Research or applied studies have already shown how operating with potentially low hydrogen quality including contaminants and different anode fuel feeding modes have a strong impact on the fuel cell behaviour, performance level and stability [73-76]. The activities on the fuel cell stack in ReforCELL were focused on the development of a suitable prototype to be integrated in the final system and evaluation of the performance and short term durability. The research included the selection of relevant core components available as commercial products or at prototype level, the definition of sets of operating conditions relevant for the application considered, and the test of 
short stacks applying these conditions to get additional information for the dimensioning of the system. Performance tests were performed as well as some durability tests to evaluate short term stability.

Short stacks (6 or 8 cells) were made with Membrane Electrodes Assemblies (MEAs) adapted for reformate fuel operation. Operating conditions were defined based first on state of the art and then on information from the partners such as system requirements for the fuel cell temperature, fuel and air gases pressures, flow rates, humidification, and of course fuel composition. The impact of fuel composition was evaluated comparing pure hydrogen with mixtures including mainly hydrogen, carbon dioxide $\left(\mathrm{CO}_{2}\right)$, and some carbon monoxide $(\mathrm{CO})$. The effect of adding some air (air bleeding operation, in the range $0.5 \%$ to $2 \%$ of air in the fuel) to reduce the impact of $\mathrm{CO}$ was also studied. Two operating modes for fuel feeding were tested: fuel circulation with fixed stoichiometric ratio and a few tests to check the fuel cell behaviour in dead end mode with purges.

It was possible to evaluate the performance of the stack with different gas feeding conditions and to validate that the operating points in terms of cell current/voltage were in the expected range (vs. reference case definition). The impact of some fuel compositions was evaluated considering the voltage losses (in \%) versus pure $\mathrm{H}_{2}$.

Within the operating range of $0.35 / 0.45 \mathrm{~A} / \mathrm{cm}^{2}$, the polarization curves showed that replacing pure hydrogen by a synthetic reformate including $\mathrm{CO}_{2}$ and some $\mathrm{CO}$ has a negative impact but limited to $5 \%$ if the $\mathrm{CO}$ concentration is less than $10 \mathrm{ppm}$. Air bleeding allowed recovering half of the voltage losses in the same current density range.

The results achieved in dead-end mode with pure hydrogen show that the stack can operate with a homogeneous behaviour of the cells with a selected rhythm for the purges, needed to remove the inert gas and water.

In parallel, performance stability was also evaluated by different load cycles, with a day/night type current profile and then following a more specific daily profile planned for the application. The latter was applied to check the capability of the stack to follow this utilisation profile with different fuel compositions (Figure 10a) and stack performance was then validated by recording polarisation curves (Figure 10b).
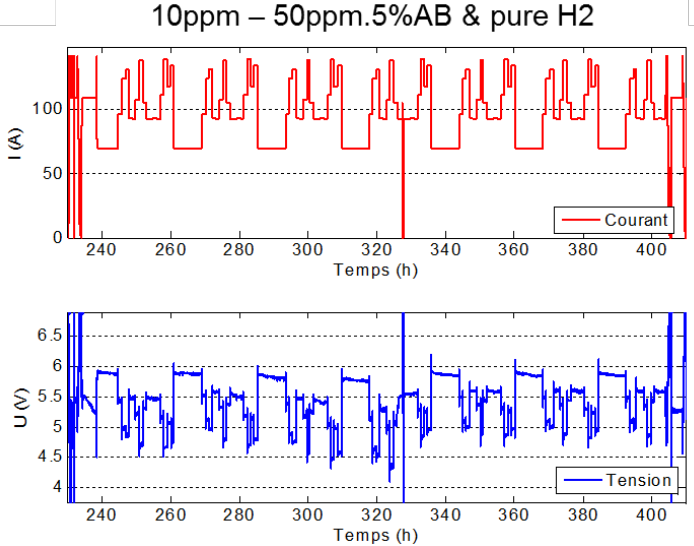

(a)

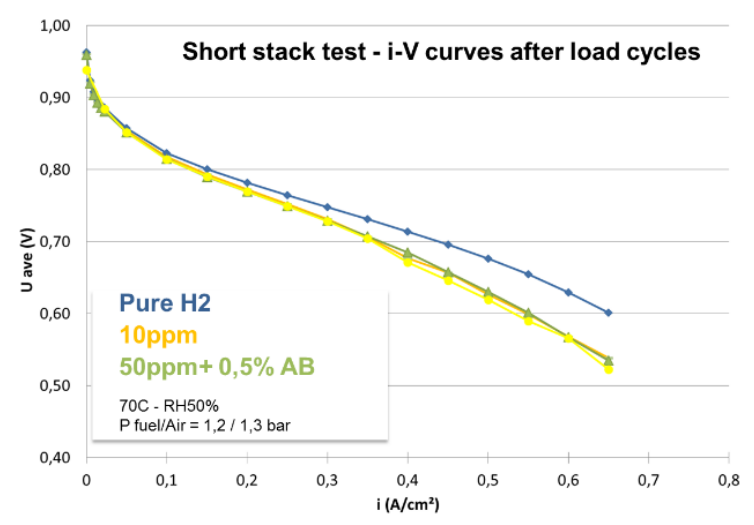

(b)

Figure 10. (a) Load cycles and stack voltage applied during more than $250 \mathrm{~h}$ under pure $\mathrm{H}_{2}$, $\mathrm{H}_{2}+10 \mathrm{ppm} \mathrm{CO}$ or $\mathrm{H}_{2}+50 \mathrm{ppm} \mathrm{CO}+0.5 \%$ Air Bleeding and (b) Polarisation curves of the short stack after Load Cycles (LC).

More extreme conditions were also checked particularly on the impact of low relative humidity, low pressures, low hydrogen flows, and high CO contents ( $>50 \mathrm{ppm})$ to check the possible effect of issues related to the system management or to the processor (Figure 11). 


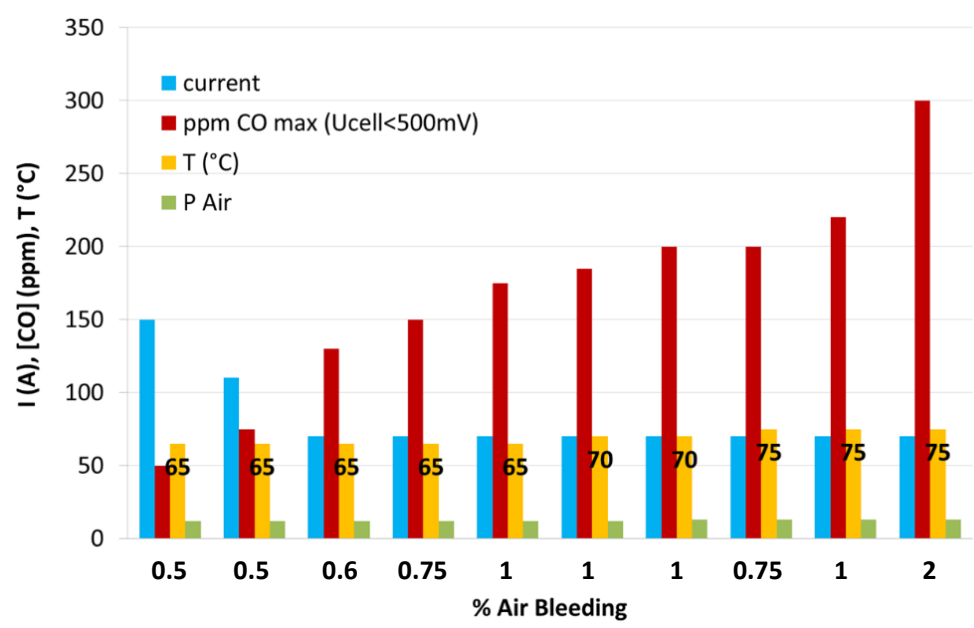

Figure 11. Data extracted from a test conducted on a PEM fuel cell short stack to check the tolerance to high CO contents. Maximum CO (red) vs. Air bleeding \% needed to maintain cell voltage average higher than $0.5 \mathrm{~V}$ by cell.

The prototype stack (specific end-plates) was designed, assembled and tested under pure hydrogen. It is made of 85 cells targeting more than $5 \mathrm{~kW}$ at nominal point and $8 \mathrm{~kW}$ maximum electric power (Figure 12). The effect of some parameters important for the system operation was checked showing no impact of stack temperature between $65^{\circ} \mathrm{C}$ and $70{ }^{\circ} \mathrm{C}$, no impact of fuel relative humidity in the foreseen application range, and around $20 \mathrm{mV} /$ cell gap at nominal point for air pressure between 1.2 and 1.5 bars.

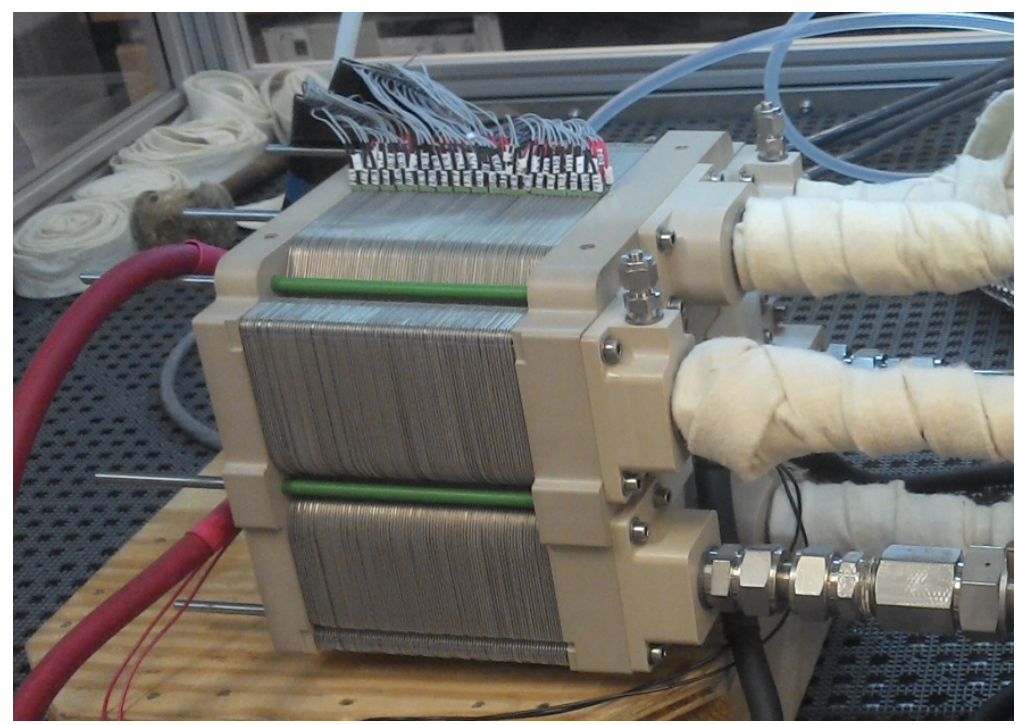

Figure 12. Picture of the CEA 85 cells Fuel Cell Stack prototype.

Under the nominal operating conditions and pure hydrogen, the prototype showed the same performance (average cell voltage) as the short stack (Figure 13). 


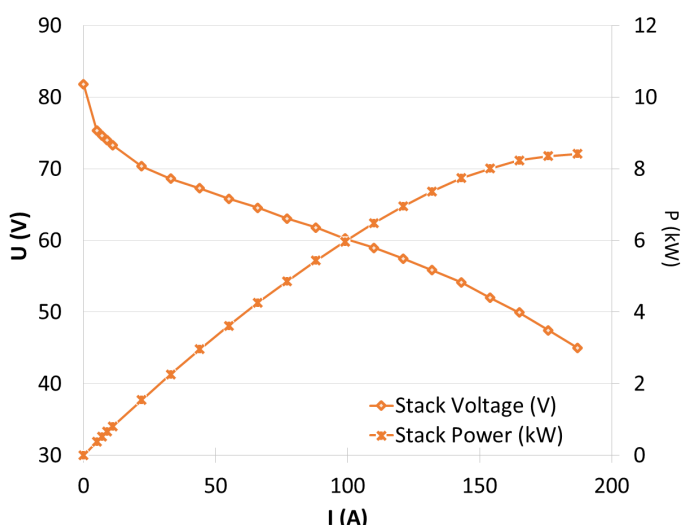

(a)

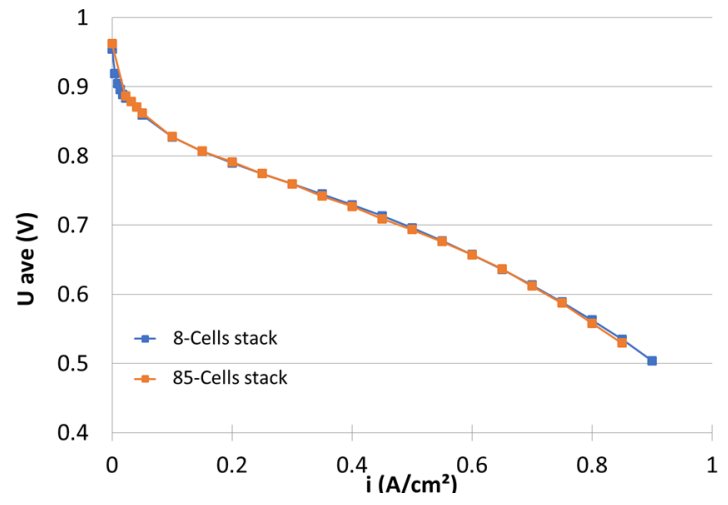

(b)

Figure 13. (a) Polarisation curves and power of the prototype stack under pure hydrogen and (b) Comparison of average stack cells voltage of the prototype 85-cells stack (orange) and the 8-cells stack (blue) under nominal ReforCELL conditions: $65^{\circ} \mathrm{C}, 1.2$ bar, 50/50 \%RH, st1.5/2.

\section{Results and Discussion}

In this section the main outcomes obtained from the ReforCELL project are presented. The research activities addressed the whole product chain: i.e., development of materials/components (membranes, supports, seals, catalyst, etc.) through integration/validation at lab-scale, until development/validation of pilot scale ATR-CMR and the proof of concept/validation of the new PEM fuel cell m-CHP system. Due to this fact, this section is divided into different sub-sections containing the main results.

\subsection{Catalyst}

A novel ruthenium based ATR catalyst consisting of $2 \%$ ruthenium on a ceria zirconia support was developed fulfilling the requirements of ReforCELL (active and stable catalyst at low temperature $\sim 600^{\circ} \mathrm{C}$ ). The synthesis of the catalyst is based on a sequential procedure where first the ceria-zirconia support, having the overall formula $\mathrm{Ce}_{0.75} \mathrm{Zr}_{0.25} \mathrm{O}_{2}$, is prepared. This support is then fractionized to the desired particle size and subsequently loaded with the active ruthenium metal. Initial tests showed that controlled precipitation gives the best result for the support in terms of surface area and particle size.

A set of different support particle sizes was sent to TU/e for testing of the fluidization behaviour in a fluidized bed reactor. The tests showed stable fluidization behaviour for the different particle sizes. In addition to the support an inert material having the same bulk density and particle size as the support was sent to TU/e. Fluidization tests showed that there was no separation of the support and inert filler under fluidization conditions. From the tests the fraction having a particle size of $125-250 \mu \mathrm{m}$ was chosen as the most interesting candidate for the pilot scale reactor.

XRD analysis of the $\mathrm{Ce}_{0.75} \mathrm{Zr}_{0.25} \mathrm{O}_{2}$ support shows that the material exhibits the cubic structure of the ceria. The absence of monoclinic and tetragonal zirconia phases, when using the co-precipitation methods, indicates that the zirconium is incorporated into the ceria structure (Figure 14). The average crystallite size of $30 \mathrm{~nm}$ as derived from the line broadening is in accordance with the high resolution TEM images of the material. From the XRD and physisorption there is no difference between the materials made on laboratory or kilogram scale. This shows that the support was successfully prepared at kilogram scale. The high BET surface area of $\sim 90 \mathrm{~m}^{2} / \mathrm{g}$ is a direct result of the small crystallite size as seen in the XRD and TEM measurements. 


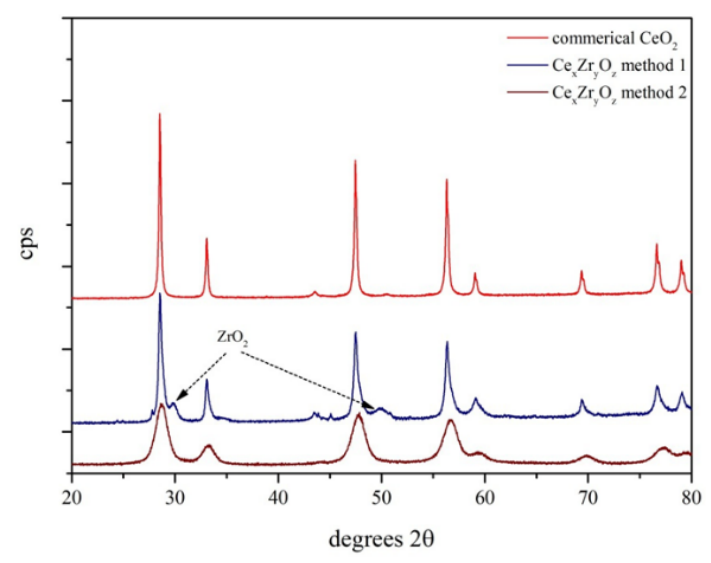

(a)

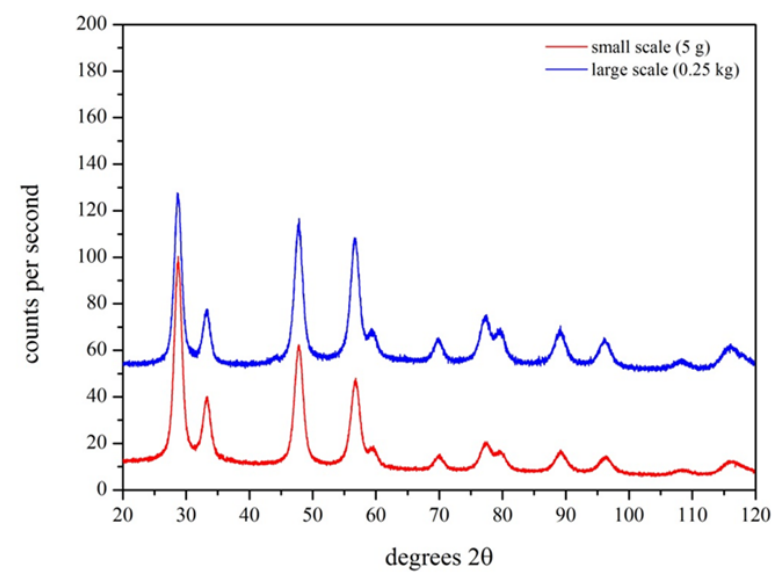

(b)

Figure 14. (a) XRD diffractogram of the support prepared via different methods and (b) comparison of small and large scale preparation.

The ruthenium was loaded onto the support via controlled precipitation. This technique combines a good dispersion with the possibility of upscaling whereas incipient wetness has a poor dispersion and surfactant assisted routes are more difficult to scale up. The ruthenium load of $2 \%$ was confirmed by XPS analysis of the catalyst. Both XRD and $\mathrm{N}_{2}$ physisorption did not show large changes in the material after the ruthenium loading (Figure 15), which shows that the original structure of the support was preserved during the loading.

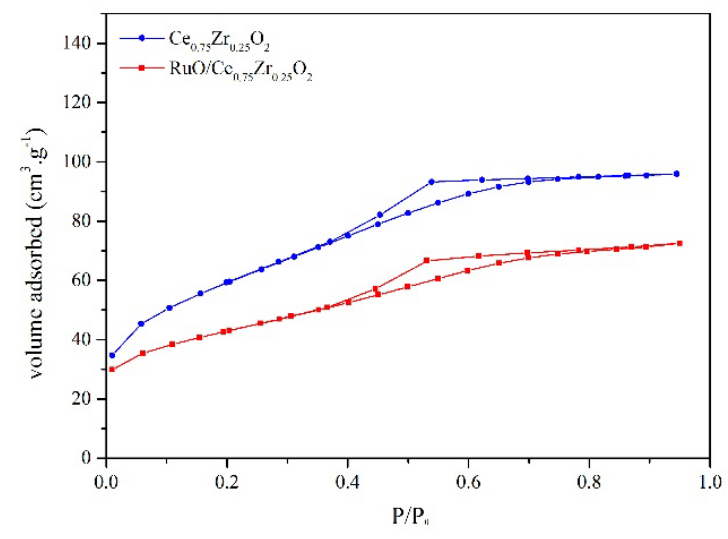

(a)

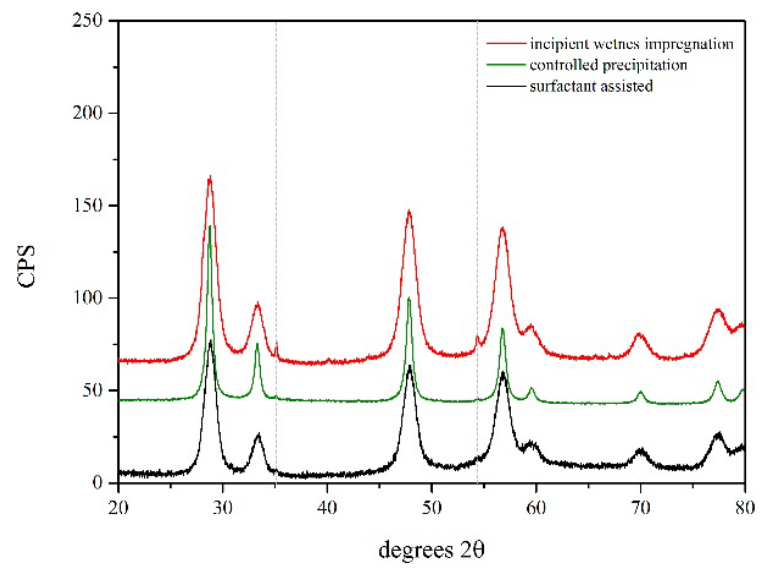

(b)

Figure 15. (a) Nitrogen physisorption and (b) XRD of the ruthenium based low temperature ATR catalyst.

The new catalyst was tested for its performance in a custom built lab scale reactor. During the test, the conditions were varied to test the performance of the catalyst under the various conditions that can be expected in the pilot plant reactor. Figure 16 gives an overview of the performance of the ruthenium based ATR catalyst both under SMR and ATR conditions. The graph shows that the hydrogen production over the catalyst is stable under the various SMR and ATR conditions, and that the catalyst operates at the desired low temperature window of $500-600{ }^{\circ} \mathrm{C}$. 


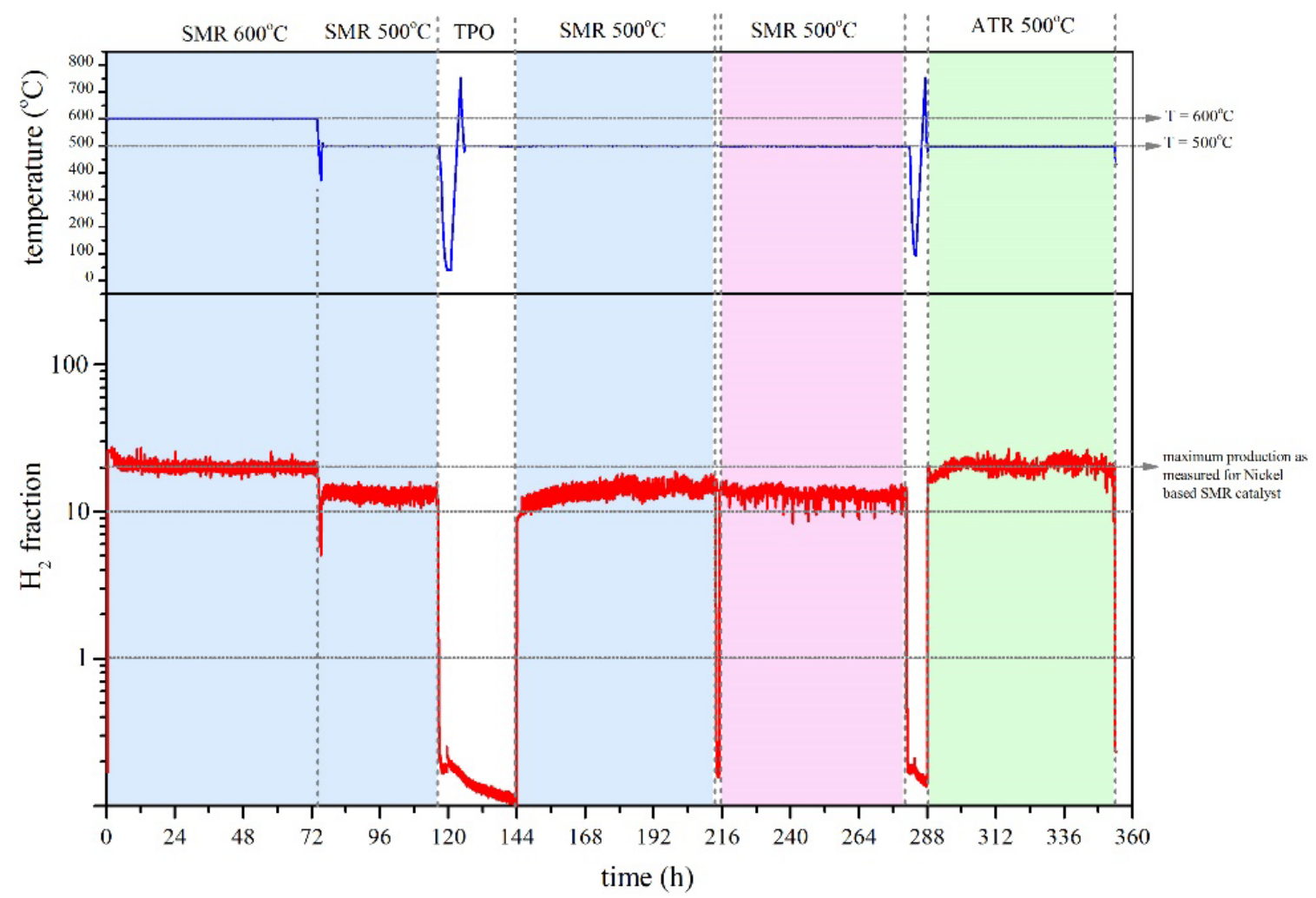

Figure 16. Hydrogen production under various conditions during a $360 \mathrm{~h}$ test run of the low temperature reforming catalyst.

There are no commercially available Ni catalysts that meet the requirement of low temperature methane reforming targeted in the project. To meet with the demand of an active and stable catalyst at low temperature, catalysts based on Noble metals as $\mathrm{Pt}$, $\mathrm{Rh}$ or $\mathrm{Ru}$ were developed. Based on scientific literature, such catalysts are particularly suitable when supports based on ceria or zirconia are employed, and especially mixed zirconia/ceria supports. Given noble metal pricing, Ru based catalysts would be most economical. The developed Ru based ATR catalyst achieved the required targets proposed in the project related to activity, selectivity, and stability. An important finding was that the catalyst is also active at significant lower temperature than originally anticipated $\left(500{ }^{\circ} \mathrm{C}\right)$.

\subsection{Lab Scale Reactors}

The catalyst and membranes were combined to demonstrate the concept at lab scale. Two different reactor configurations were selected for the lab scale demonstration of the reforming reaction in the membrane reactor: micro-channel reactor and fluidized bed membrane reactor.

\subsubsection{Micro-Channel Reactor}

Micro-structured membrane modules that reduce gas phase diffusion limitations and increase the membrane area to reactor volume ratio compared to traditional tubular reactors were developed in the project (Figure 17). Since concentration polarization effects are expected to be reduced in such modules, a high space-time-yield is anticipated due to the available high volumetric surface area for reaction and membrane separation.

The long-term stability of various designs of microstructured membrane modules has extensively been investigated [57]. In the experiments, the $\mathrm{H}_{2}$ permeation performance and stability of the modules were verified over a period of up to 50 days. Operation of micro-channel modules that employ a stainless steel plate with apertures on the permeate side results in a large settling of the film into the 
permeate section; ultimately this will result in a membrane failure. The operation limits are $\sim 450{ }^{\circ} \mathrm{C}$ and pressures up to 5 bar.

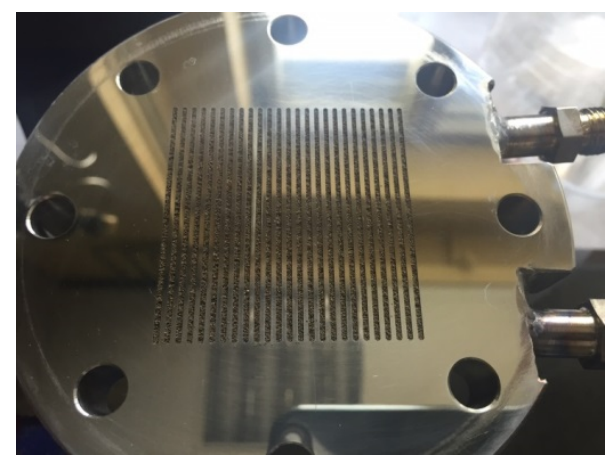

(a)

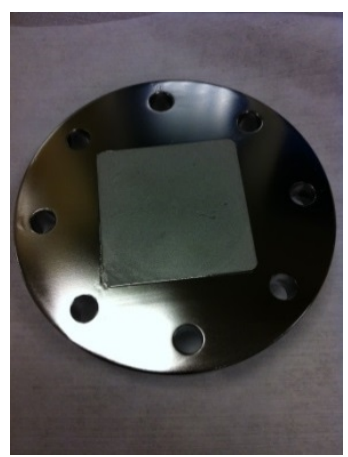

(b)

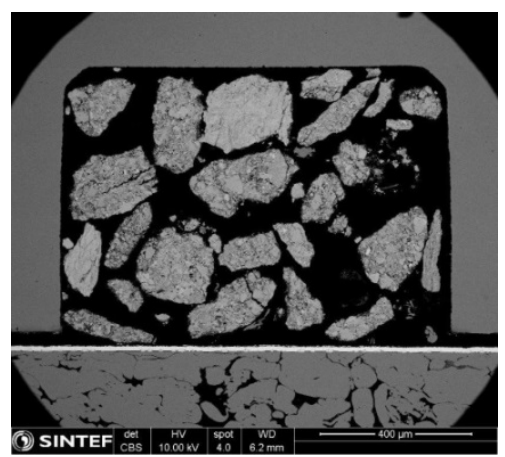

(c)

Figure 17. (a) Microchannel reactor feed side with $\sim 1.8 \mathrm{~g}$ of catalyst in 25 channels of $25 \times 1 \times 1 \mathrm{~mm}$; (b) PSS permeate section; and (c) cross-section SEM micrograph of a 10 micron-thick $\mathrm{Pd}_{77} \mathrm{Ag}_{23}$ film on a PSS support with catalyst in the feed channels (after $1300 \mathrm{~h}$ of operation).

For pressures above 5 bar a porous stainless steel (PSS) support is introduced for sufficient stabilisation of the $\mathrm{Pd}_{77} \mathrm{Ag}_{23}$ films (see Figure 17c). For such a module, a hydrogen flux of $195.3 \mathrm{~mL} \cdot \mathrm{min}^{-1} \cdot \mathrm{cm}^{-2}$ was obtained at $5 \mathrm{bar}$ and $450{ }^{\circ} \mathrm{C}$. The module shows a very good stability up to the highest feed thin pressure applied of 15 bar at a $\mathrm{H}_{2} / \mathrm{N}_{2}$ ideal perm-selectivities $>39,000$. The temperature stability was improved by the introduction of YSZ IMDBL, and selective operation was obtained for $160 \mathrm{~h}$ at $550{ }^{\circ} \mathrm{C}$.

Integrated membrane reformer systems were tested up to 8 bar and $550{ }^{\circ} \mathrm{C}$ during periods of up to 75 days applying either a commercial JM Hifuel Ni-based catalyst or the $\mathrm{Ru} / \mathrm{Ce}_{0.75} \mathrm{Zr}_{0.25} \mathrm{O}_{2}$ catalyst developed in ReforCELL in the feed channels, see Figure 17. The results show that the Ru-based catalyst is less prone to coke formation than the commercial Ni-catalyst and more active at low temperatures. The performance of the Ru-catalyst integrated reactor system was limited by the $\mathrm{H}_{2}$ removal rate through the membrane. Compared to the conventional packed-bed reactor with an equilibrium methane conversion $<40 \%$, the continuous hydrogen removal shifts the equilibrium and therefore a higher methane conversion is obtained. At a W/F ratio of $27 \mathrm{~g}_{\mathrm{cat}} \mathrm{h} / \mathrm{mol}_{\mathrm{CH} 4}\left(\mathrm{GHSV}=6000 \mathrm{~h}^{-1}\right)$, a methane conversion $>95 \%$ and $\mathrm{H}_{2}$ production rate of $4.5 \mathrm{Nm}^{3} \cdot \mathrm{m}^{-2} \cdot \mathrm{h}^{-1}$ was obtained at $550{ }^{\circ} \mathrm{C}$ and a feed pressure of 6 bar, see Figure 18.

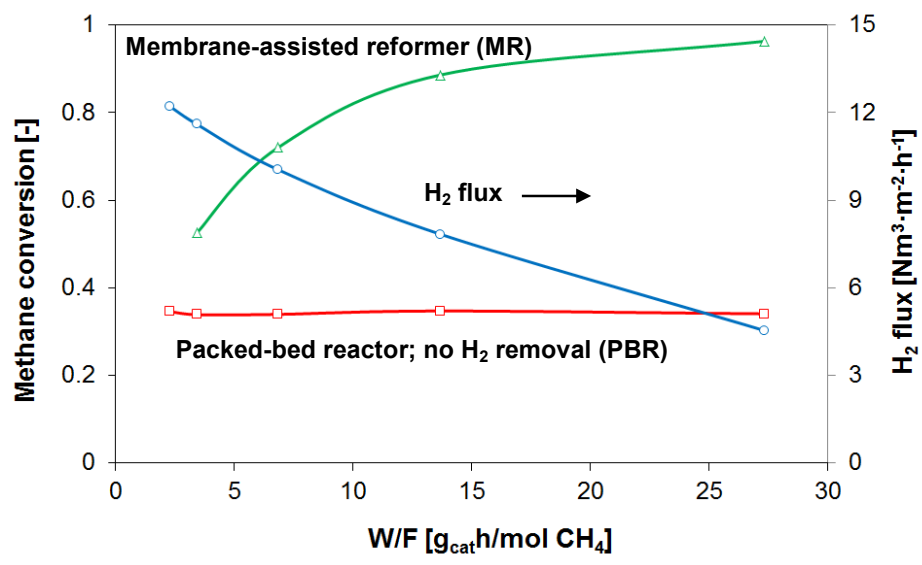

Figure 18. Methane conversion and $\mathrm{H}_{2}$ flux as function of the $\mathrm{W} / \mathrm{F}$ ratio at $550{ }^{\circ} \mathrm{C}$ and $\mathrm{S} / \mathrm{C}=3$ for the membrane-assisted reactor (MR) and a conventional packed-bed reactor (PBR) (red line); GHSV $=6000-72,000 \mathrm{~h}^{-1} ; \mathrm{N}_{2}: \mathrm{CH}_{4}: \mathrm{H}_{2} \mathrm{O}=20: 20: 60$. 


\subsubsection{Fluidized Bed Membrane Reactor}

The procedure followed to validate the fluidized bed membrane reactor concept was similar to the line-time presented for the microchannel reactor. The catalyst and membrane stability were first investigated separately. Later on, both were integrated in the reactor and tested under steam reforming and autothermal reforming of methane in fluidized bed membrane reactors. Two different types of membranes were tested: Pd-based tubular ceramic supported membranes (Figure 4) and Pd-based tubular metallic supported membranes (Figure 5) both developed by direct simultaneous Pd and Ag electroless plating (ELP) deposition [51-54] in a one step process.

Characterization of the Ru supported catalyst showed that the catalyst particles are mechanically stable in fluidized bed operation and no loss of particle size was observed even under high temperature operation in a bubbling fluidization regime.

The stability and sealing of the ceramic supported Pd-based membranes were also investigated. The Pd-based tubular ceramic supported membranes were sealed using commercial standard Swagelok connectors (316 SS) together with graphite gaskets for $10 \mathrm{~mm}$ OD tubes provided by CHROMalytic TECH(nology) Pty Ltd (Boronia, Victoria 3155, Australia). The graphite gaskets were sized to the outer membrane diameter of 10.1-10.5 $\mathrm{mm}$ and pretreated with a membrane dummy to the standard Swagelok connector. Figure 19 shows a schematic of the sealing (a) and a picture of the sealed tubular Pd-alloy membrane with graphite gaskets to a standard Swagelok connector (b). The bottom part of the connector was specially designed for membranes that will be immersed vertically in the fluidized bed to avoid gas holdup below the membrane. In case of integration in packed bed reactors, simple Swagelok caps could be used.

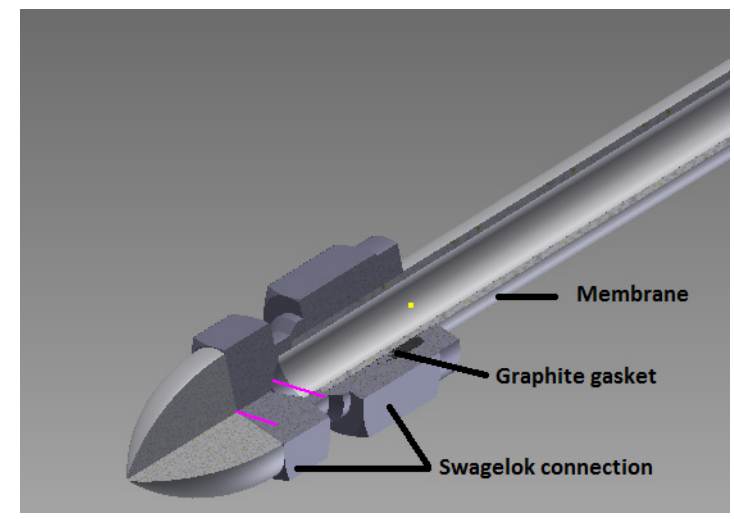

(a)

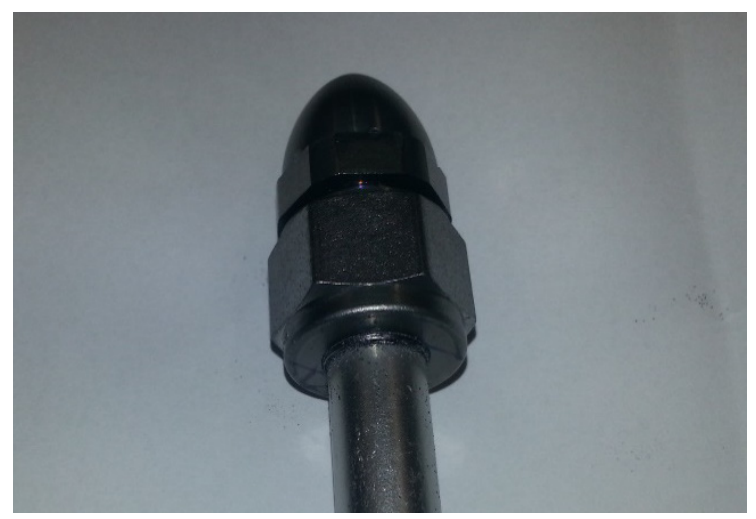

(b)

Figure 19. (a) Schematic of the graphite based sealing and (b) photograph of sealed tubular membrane. Reproduced with permission from [51] Copyright, 2015, Elsevier.

The membranes were tested for single gas permeation, mixed gas permeation, and for steam reforming and autothermal reforming of methane in fluidized bed membrane reactors. The hydrogen flux through a sealed membrane at different hydrogen partial pressures and different temperatures between $380-600{ }^{\circ} \mathrm{C}$, and after the stability tests were performed, is shown in Figure 20a. The hydrogen permeation rate increases with increasing transmembrane partial pressure difference and temperature, as expected. The tested membrane shows an almost perfect linear behaviour for the pressure exponential factor $n=0.5\left(R^{2}>0.995\right)$, which is typical for Pd-alloy membranes at low pressures, if bulk-diffusion through the membrane is the rate limiting step according to Sieverts' law [77]. The membrane parameters for the tested membrane were determined at $10 \mathrm{~kJ} \cdot \mathrm{mol}^{-1}$ for the activation energy $\left(\Delta \mathrm{E}_{\text {act }}\right)$ and $6.93 \times 10^{-8} \mathrm{~mol} \cdot \mathrm{m}^{-2} \mathrm{~Pa}^{-0.5} \cdot \mathrm{s}^{-1}$ for the pre-exponential factor $\left(\mathrm{P}_{0}\right)$ using the plot of the logarithm of the permeance against the reciprocal temperature (shown in Figure 20b). 


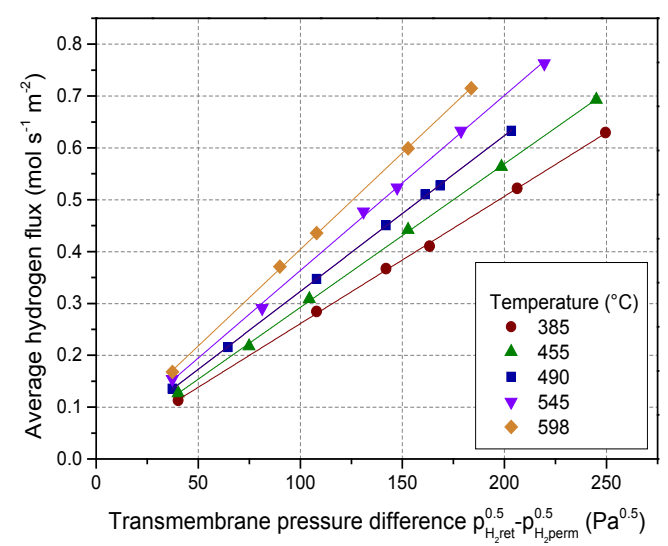

(a)

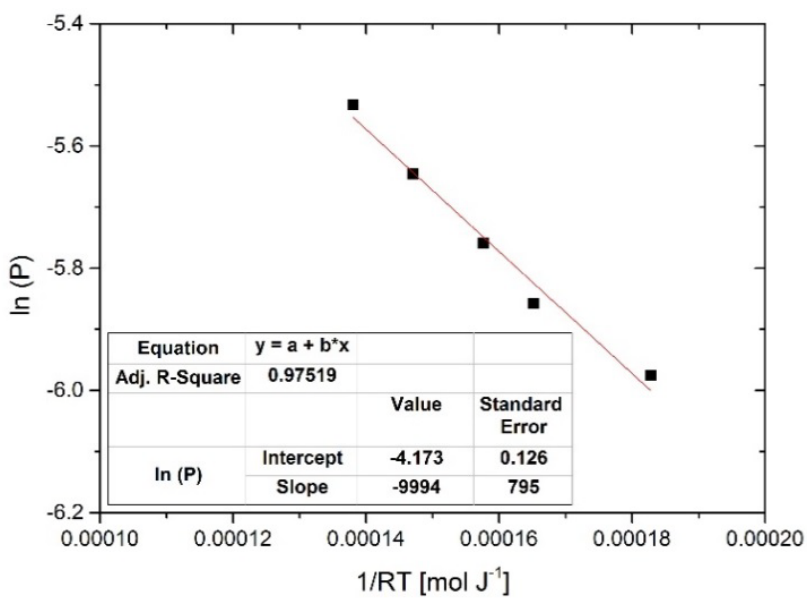

(b)

Figure 20. (a) $\mathrm{H}_{2}$ flux vs. $\mathrm{H}_{2}$ partial pressure difference at different temperatures for fresh sealed membranes after thermal cycling tests and (b) linear regression to determine membrane parameters (intercept value is $\ln \left(\mathrm{P}_{0}\right)$ and slope is $-\mathrm{E}_{\text {act }}$ in $\mathrm{J} / \mathrm{mol}$ ). Reproduced with permission from [51] Copyright, 2015, Elsevier.

The first test with five tubular ceramic supported membranes was performed with conventional SMR. Figures 21 and 22 show the obtained retentate compositions together with the achieved methane conversion. It can be seen that methane conversion increases with increasing temperatures, where the extracted hydrogen stream includes a noticeable amount of CO. Nevertheless, the hydrogen purity still remains above $99.98 \%$ for all cases. During the experiments it was observed that the amount of $\mathrm{CO}$ in the permeate stream increased from the first day of tests to the second day of tests at the same operation conditions. An increase of the temperature also leads to an increase of the CO impurity in the permeate stream.

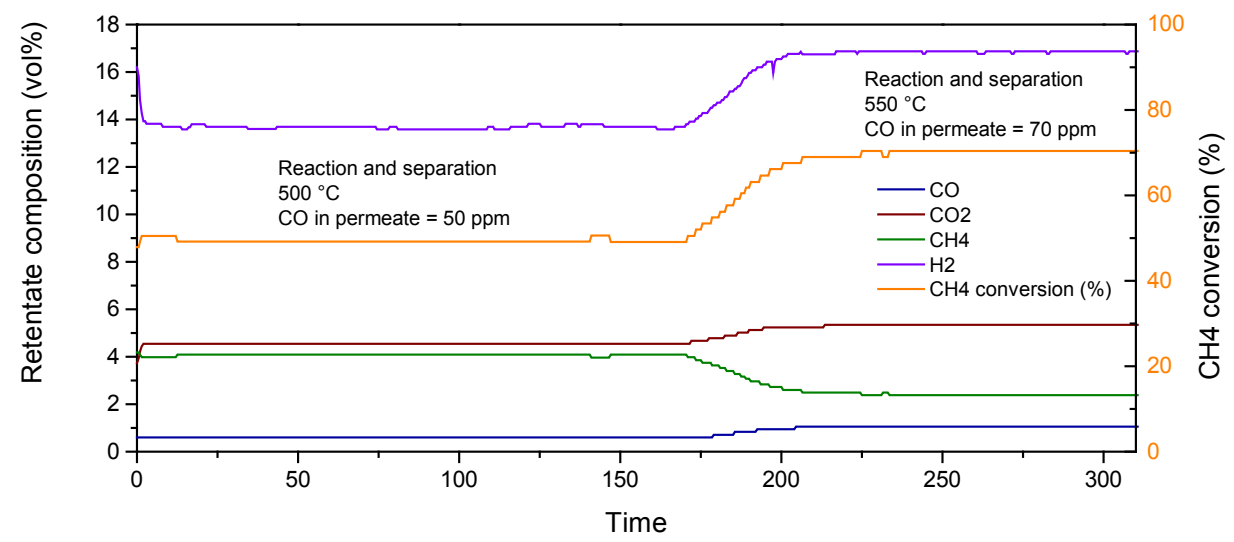

Figure 21. Steam methane reforming (SMR) in a FBMR with five tubular ceramic supported membranes at 500 and $550{ }^{\circ} \mathrm{C}$ and a pressure of 1.3 bar. Feed: S/C of 3 and a N/C of 8.4 with a total flow rate of $10.3 \mathrm{NL} / \mathrm{min}$. Reproduced with permission from [51] Copyright, 2015, Elsevier.

Table 3 gives a summary of the different operating conditions used in the SMR tests. The results clearly show the increase in hydrogen recovery at higher temperatures due to the increased hydrogen permeability of the membranes at higher temperatures. During the first day of tests the equilibrium conversion was reached as expected, but remarkably during the second day of experiments, the methane conversion was higher at the same operating conditions and increased even slightly beyond the equilibrium conversion. Comparing the equilibrium conversion of methane and the 
conversion obtained during the experiments, especially in the second day, a significant increase was detected. Analysing the surface of the membranes and the sealing after these tests, it was observed that the sealing was damaged, which could be the reason for the $\mathrm{CO}$ increase in the permeate gas stream. The membrane surface was free of defects, which assures that the membranes can survive under reforming conditions for this test duration.

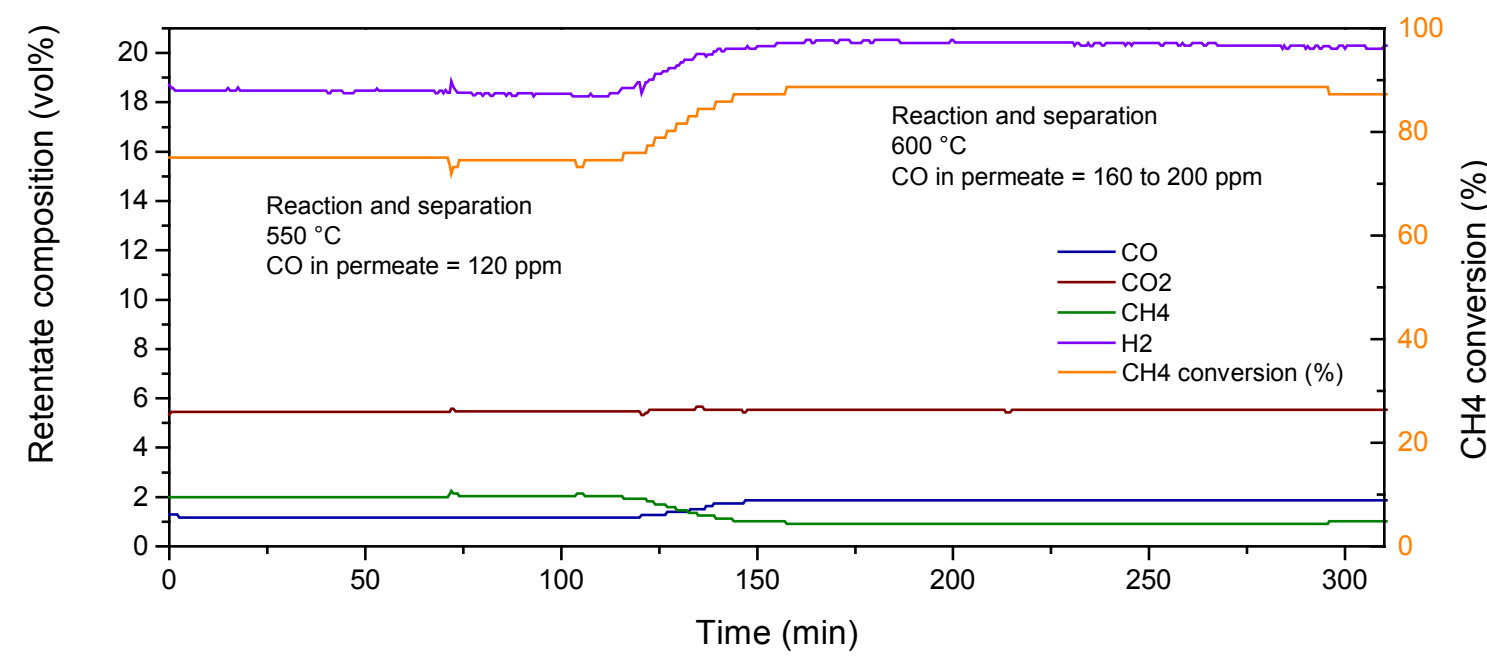

Figure 22. Steam methane reforming (SMR) in a FBMR with five tubular ceramic supported membranes at 550 and $600{ }^{\circ} \mathrm{C}$. Feed: S/C of 3 and a N/C of 8.4 with a total flow rate of $10.3 \mathrm{NL} / \mathrm{min}$ to ensure fluidization. Reproduced with permission from [51] Copyright, 2015, Elsevier.

Table 3. Summary of SMR in the FBMR with tubular $\mathrm{Pd}-\mathrm{Ag} / \mathrm{ZrO} \mathrm{F}_{2}$ membranes at 1.3 bar at several temperatures. Reproduced with permission from [51] Copyright, 2015, Elsevier.

\begin{tabular}{|c|c|c|c|c|}
\hline \multirow{2}{*}{$\begin{array}{c}\text { Day of Membrane Tests } \\
\text { System pressure (bar) }\end{array}$} & \multicolumn{2}{|c|}{ Day 1} & \multicolumn{2}{|c|}{ Day 2} \\
\hline & 1.3 & 1.3 & 1.3 & 1.3 \\
\hline System temperature $\left({ }^{\circ} \mathrm{C}\right)$ & 500 & 550 & 550 & 600 \\
\hline $\mathrm{CH}_{4}$ eq. conversion $(\%)$ & 55.7 & 73.0 & 73.0 & 88.1 \\
\hline$u / u_{m f}(-)$ & 1.3 & 1.3 & 1.3 & 1.3 \\
\hline Volumetric flow rate in reactor $(\mathrm{L} / \mathrm{min})$ & 20.9 & 22.3 & 22.3 & 24 \\
\hline $\mathrm{CH}_{4}$ conversion $(\%)$ & 55.5 & 73.1 & 76.4 & 89.3 \\
\hline Exhaust $\mathrm{H}_{2} / \mathrm{CO}$ ratio (-) & 22.6 & 16.1 & 15.8 & 11 \\
\hline CO selectivity (-) & 0.12 & 0.16 & 0.18 & 0.25 \\
\hline $\mathrm{H}_{2}$ selectivity (-) & 3.85 & 3.79 & 3.83 & 3.74 \\
\hline $\mathrm{H}_{2}$ recovery factor $(\mathrm{HRF})(-)$ & 0.17 & 0.22 & 0.2 & 0.23 \\
\hline $\mathrm{H}_{2}$ separation factor (HSF) (-) & 0.31 & 0.31 & 0.28 & 0.28 \\
\hline Hydrogen permeate impurity (ppm CO) & 50 & 70 & 120 & 200 \\
\hline Hydrogen permeate flow (NmL/min) & 550 & 740 & 700 & 800 \\
\hline
\end{tabular}

In a second test, ATR of methane was performed on these membranes. The retentate stream composition and methane conversion are shown in Figure 23. The feed conditions were different to the test performed with the REB membranes, so the results obtained in terms of conversion of methane cannot be directly ascribed to the different membranes, while the hydrogen recovery and separation can. 


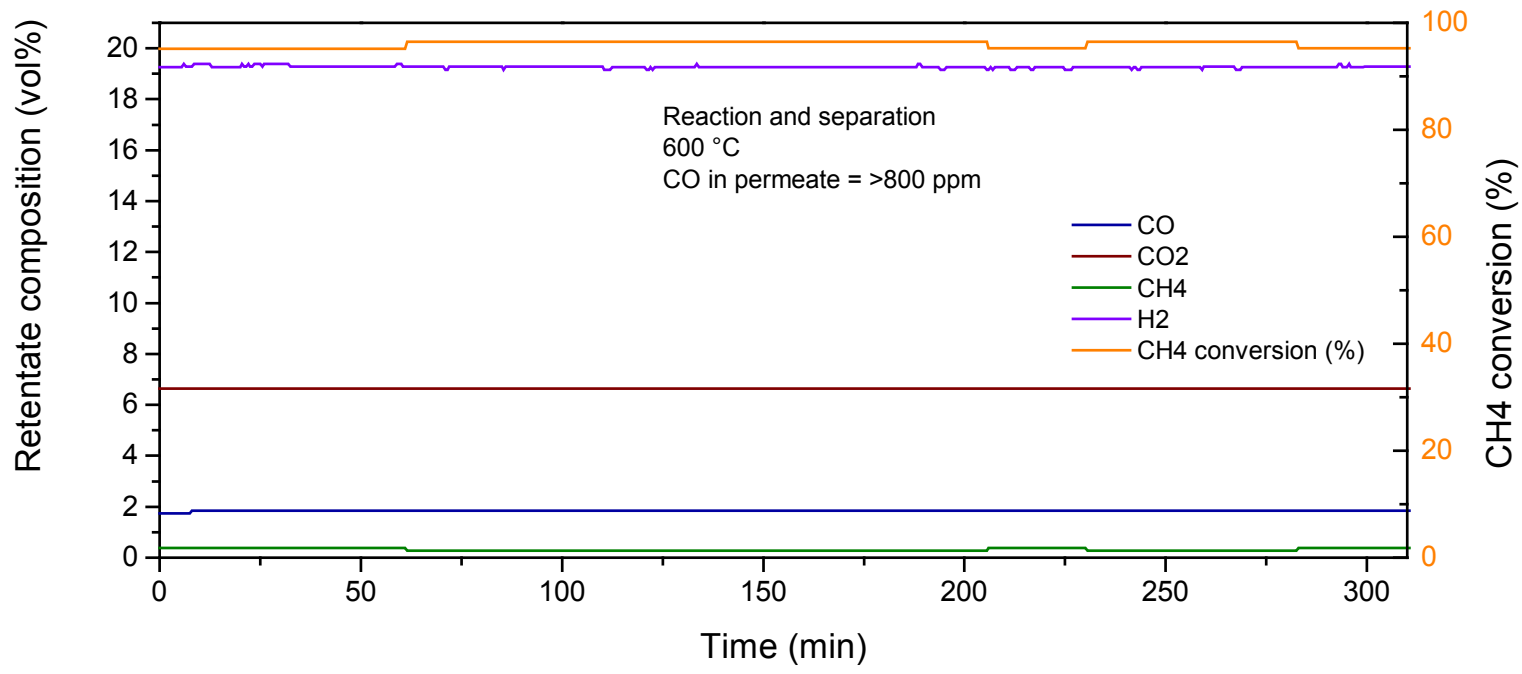

Figure 23. Autothermal reforming of methane (ATR) in a FBMR with five membranes at $600{ }^{\circ} \mathrm{C}$. Feed: $\mathrm{S} / \mathrm{C}$ of $3, \mathrm{O} / \mathrm{C}$ of 0.25 and an $\mathrm{N} / \mathrm{C}$ of 8.2 . Total feed flow rate $10.3 \mathrm{NmL} / \mathrm{min}$. Reproduced with permission from [51] Copyright, 2015, Elsevier.

Comparing the results obtained for ATR reforming without and with the TECNALIA membranes, which are shown in Table 4, the methane conversion increased by $7.2 \%$ from $89.5 \%$ to $96.7 \%$. The total amount of produced hydrogen increased by $7.7 \%$ resulting in a total flow rate of hydrogen of $2.71 \mathrm{~L} / \mathrm{min}$. The hydrogen recovery and the purity of the hydrogen stream are still comparable. Detailed information on the preparation, characterization, and stability tests of thin-film $\mathrm{Pd}-\mathrm{Ag}$ ceramic supported membranes for high-temperature fluidized bed membrane reactor applications can be found in Fernandez et al. [51].

Table 4. Comparison of ATR without membranes, with REB membranes and with tubular ceramic supported membranes. Reproduced with permission from [51] Copyright, 2015, Elsevier.

\begin{tabular}{cccc}
\hline & Without Membranes & REB Membranes & TECNALIA Membranes \\
\hline $\mathrm{CH}_{4}$ eq. conversion (\%) & 93.2 & 91 & 93.2 \\
$u / u_{m f}(-)$ & 1.5 & 1.5 & 1.5 \\
$\mathrm{CH}_{4}$ conversion (\%) & 89.5 & 92.9 & 96.7 \\
Exhaust $\mathrm{H}_{2} / \mathrm{CO}$ ratio (-) & 12.3 & 7.3 & 10.4 \\
$\mathrm{CO}$ selectivity (-) & 0.31 & 0.29 & 0.22 \\
$\mathrm{H}_{2}$ selectivity (-) & 3.59 & 2.77 & 3.41 \\
$\mathrm{H}_{2}$ recovery (-) & - & 0.2 & 0.35 \\
$\mathrm{H}_{2}$ separation factor (-) & - & 0.24 & 0.31 \\
$\mathrm{H}_{2}$ permeate impurities (ppm) & - & $<1.5$ & $>500$ \\
$\mathrm{H}_{2}$ permeate flow (NmL/min) & - & 845 & 870 \\
\hline
\end{tabular}

The ATR was also performed with Pd/Ag on metallic supports. First, the membrane stability was assessed between $500-600{ }^{\circ} \mathrm{C}$ for around $800 \mathrm{~h}$ (Figure 24). The main aim of this test was to check the stability of the hydrogen permeance and the nitrogen leakage through the membrane as a function of time on stream. It can be concluded that the membrane shows a really good stability for hydrogen permeation during the whole test $\left(\sim 1.3 \times 10^{-6} \mathrm{~mol} \cdot \mathrm{m}^{-2} \cdot \mathrm{s}^{-1} \cdot \mathrm{Pa}^{-1}\right)$. However, at a certain temperature the hydrogen permeance slightly decreased over time, as also reported in the literature before for this type of membranes. The nitrogen leakage through the metallic supported membrane was extremely low and even below the detection limit of the Bronkhorst flow meter $(0.01 \mathrm{~mL} / \mathrm{min})$ for almost $800 \mathrm{~h}$, which resulted in an ideal $\mathrm{H}_{2} / \mathrm{N}_{2}$ perm-selectivity higher than 200,000 . 


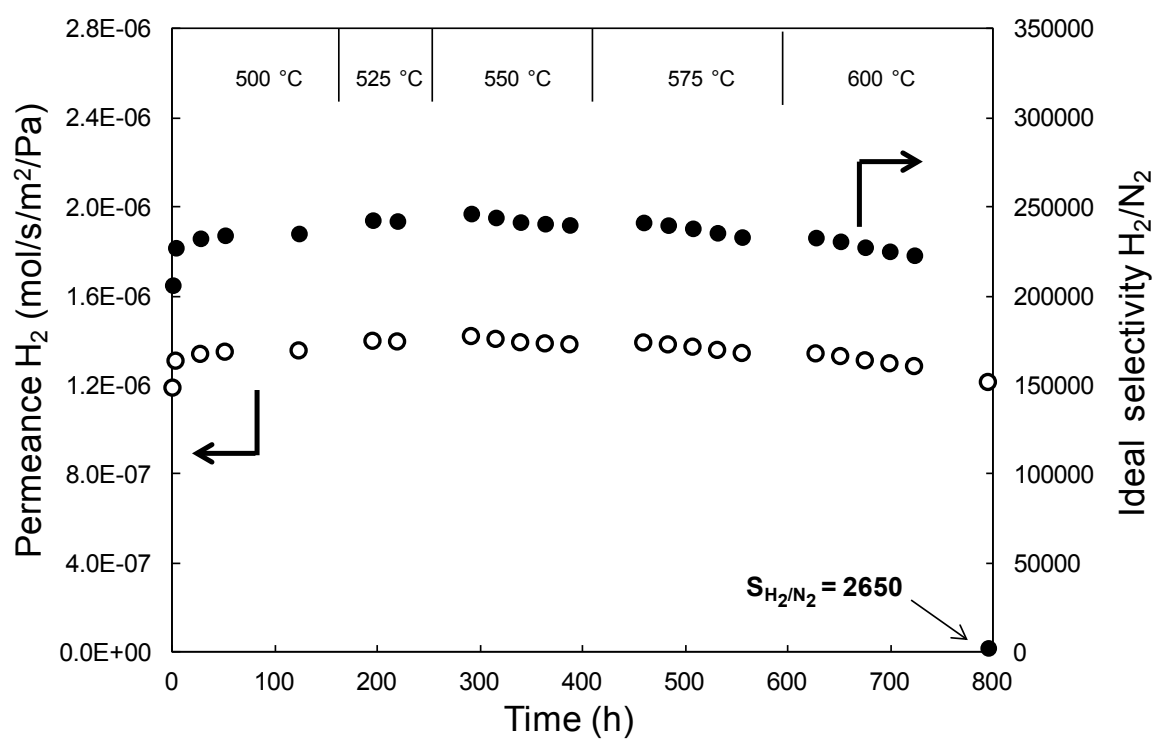

Figure 24. $\mathrm{H}_{2}$ permeance (open circles) and $\mathrm{H}_{2} / \mathrm{N}_{2}$ ideal permselectivity (closed circles) of the metallic supported membrane as a function of time on stream at $500-600{ }^{\circ} \mathrm{C}$. Reproduced with permission from [53] Copyright, 2015, Elsevier.

The test was carried out at different temperatures with a stepwise increase of $25^{\circ} \mathrm{C}$. However, once at $600{ }^{\circ} \mathrm{C}$ and after $795 \mathrm{~h}$ of permeation tests, the nitrogen permeated through the membrane resulting in a pronounced decrease in the ideal perm-selectivity which quickly dropped to a value of 2650. Nevertheless, this value of ideal perm-selectivity is still relatively high when compared to other state-of-the-art metallic supported membranes. A table with the comparison of different Pd-based membranes investigated in the literature can be found in Fernandez et al. [51,52].

Catalyst interaction with the $\mathrm{Pd}-\mathrm{Ag}$ layer was not observed since $\mathrm{H}_{2}$ permeance is the same for single gas tests with empty tube configuration and fluidized bed configuration. This also implies the absence of mass transfer resistances caused by the particles. (Close to) thermodynamic equilibrium is achieved both in ATR and SMR membrane-assisted processes. However, a full conversion of $\mathrm{CH}_{4}$ is never achieved. This can be partially explained by the large amount of inert gas fed together with the $\mathrm{CH}_{4}: \mathrm{H}_{2} \mathrm{O}$. This dramatically decreases the partial pressure of the other components. After all the experiments a decrease in ideal $\mathrm{H}_{2} / \mathrm{N}_{2}$ selectivity was $\mathrm{n}$ observed due to the defects created in the surface. As determined through a test with the membrane submerged in ethanol, all defects are associated with micropores in the surface, which were also observed with SEM images.

The methane conversion as a function of different experimental conditions for the two different reactor configurations studied in this work is shown in Figure 25.

As can be observed, chemical equilibrium is obtained in the fluidized bed reactor configuration due to the good performance of the catalyst, assuring absence of kinetic limitations. Furthermore, for all cases an important increase in the yield of the reaction for $\mathrm{H}_{2}$ production as a consequence of the displacement of the equilibrium is observed when the membrane reactor configuration is employed. It is especially interesting to highlight that the equilibrium displacement is more pronounced for conditions where the driving force for $\mathrm{H}_{2}$ permeation is maximized, such as an increase in the pressure of the reactor and the steam-to-carbon ratio, or a decrease in the total flow rate with the corresponding increase in residence time. Under the new scenario with configuration of the FBMR, the expected thermodynamic equilibrium was also calculated with Aspen Plus. As observed from Figure 25, again thermodynamic equilibrium is almost achieved in this new configuration. The difference observed might relate to the small amount of catalyst in the freeboard, which may not be enough to achieve the expected equilibrium. For all the cases studied in this work, a maximum error in the carbon balance of around $5 \%-8 \%$ is obtained as a consequence of experimental errors mainly related to the analyser 
calibration. Detailed information on the characterization and stability tests of thin-film Pd-Ag metallic supported membranes for high-temperature fluidized bed membrane reactor applications can be found in Medrano et al. [53].
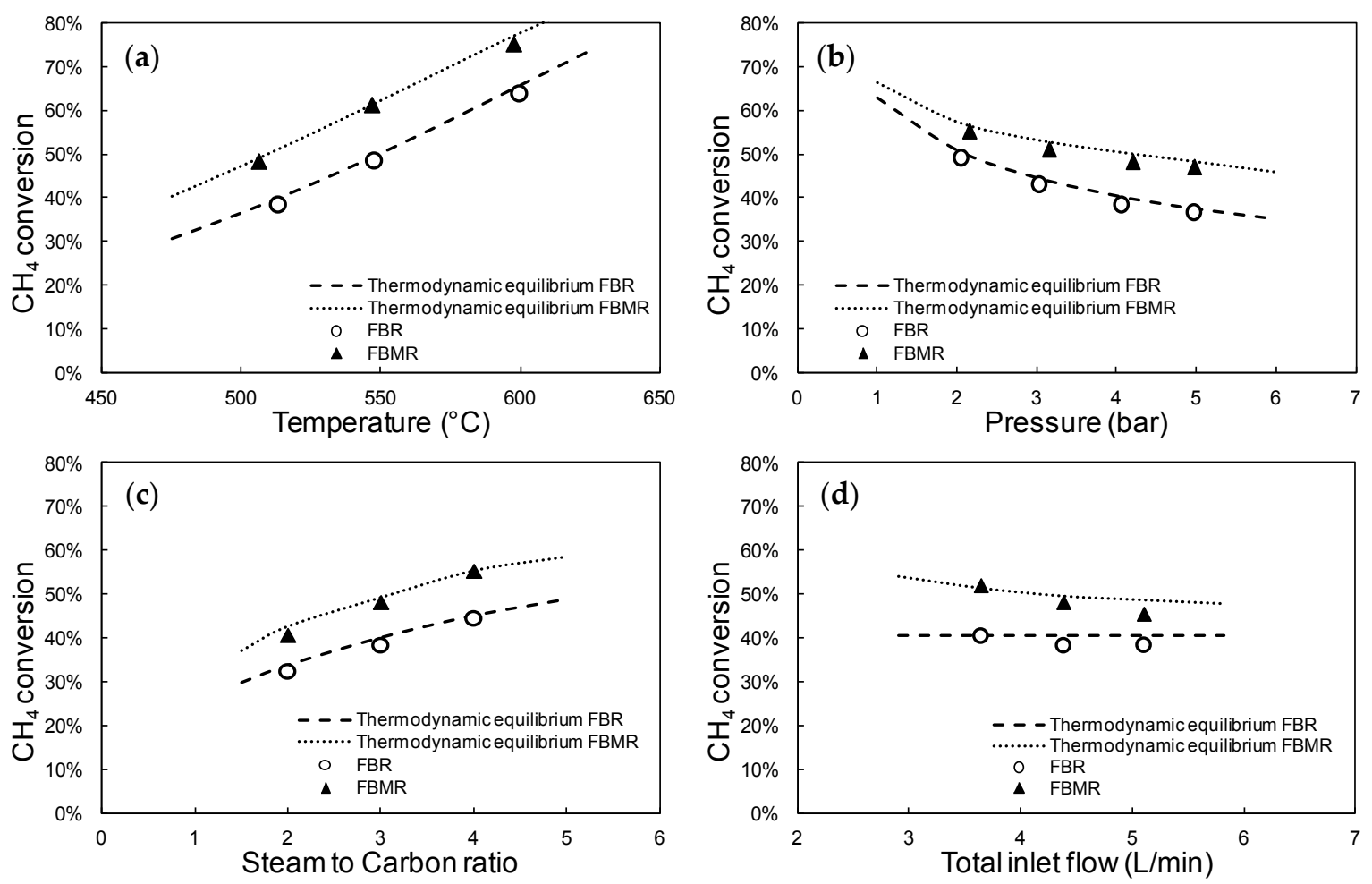

Figure 25. Methane conversion as a function of (a) temperature; (b) pressure; (c) steam-to-carbon ration and (d) inlet flow rate for the two reactor configurations studied with reference case conditions and the thermodynamic equilibrium for steam methane reforming calculated in Aspen Plus v7.3.2. Reproduced with permission from [53] Copyright, 2015, Elsevier.

\subsection{ATR Prototype}

The membrane reactor was tested for different operating conditions with ranging pressure, temperature and S/C ratio. Difficulties were found in fragility of the ceramic supports of the membranes which failed early in the testing phase. An improved protocol for handling, assembling and testing the membranes was defined for further developments to reduce this risk. The remaining tests were performed at lower flows and without extraction of hydrogen. During the testing, the ATR reactor reached a stable production of $1.7 \mathrm{Nm}^{3}$ of $\mathrm{H}_{2}$ per $\mathrm{Nm}^{3}$ of $\mathrm{CH}_{4}$ feed. Flow patterns, heat transfer limits, and integration possibilities of the reactor were identified. During testing, the performance was checked in the SCADA panel view. Several parameters (e.g., pressures, temperatures, flow rate, valve position, etc.), were also monitored by the graphical control panel.

A model was developed based on the results to simulate the fluidized bed membrane reactor. The model was used for calculation of membrane area and to analyse the influence of some variables such as reactor temperature, heat loss and operating load. The model also evaluates the required NG, air and steam flow rates to achieve the $\mathrm{H}_{2}$ production target, operating at autothermal condition.

Another model of the complete fuel processor including peripheral components of the balance of plant was also developed to describe the ATR-MR system performance. The system includes the ATR membrane reactor and the auxiliary units to recover the heat source from permeate and retentate streams. The model analyses the influence of some variables such as reactor temperature, heat loss and operating load, allowing an optimization procedure (CAPEX minimization) of the heat exchanging network. The results of the ATR-MR system model provide a sort of map of the required operating 
condition as a function of the $\mathrm{H}_{2}$ production target. By decreasing the hydrogen output, the $\mathrm{O} / \mathrm{C}$ ratio increases, and the requirements for feed of steam relative to the Natural Gas feed (S/C) decreases.

\subsection{Integration and Validation in m-CHP System}

The technical objective of this activity was the definition of the optimal lay-out for the micro-CHP system when integrating the membrane reactor and the assessment of its performance. Firstly, the indexes adopted for comparing the different configurations were defined. They are the net electric efficiency, net thermal efficiency, and overall efficiency which are defined in the EU directive for cogeneration (2004/8/EC)).

$$
\begin{aligned}
& \text { Net Electric efficiency }\left(\eta_{e l}\right)=\frac{P_{\text {net. } A C}}{\dot{m}_{f u e l} \cdot L H V_{f u e l}} \\
& \text { Net thermal efficiency }\left(\eta_{t h}\right)=\frac{\dot{Q}_{c o g}}{\dot{m}_{f u e l} \cdot L H V_{f u e l}} \\
& \text { Overall efficiency }=\frac{P_{n e t . A C}+\dot{Q}_{c o g}}{\dot{m}_{f u e l} \cdot L H V_{f u e l}}=\eta_{e l}+\eta_{t h}
\end{aligned}
$$

where

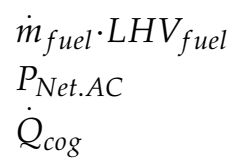

$$
\begin{aligned}
& \text { Thermal input power } \\
& \text { Net power output } \\
& \text { Net thermal power output }
\end{aligned}
$$

In addition to these, the second law analysis of the micro-CHP system is carried out to assess the overall energy losses in the conversion process. In the second law analysis, the net thermal power output is weighed by means of the efficiency of an ideal process converting the heat into work as expressed below.

$$
E x_{\text {th }}=\dot{Q}_{c o g} \eta_{\text {ideal }}=\dot{Q}_{c o g} \cdot\left(\frac{\int_{\text {Tamb }}^{\text {Tout }} c d T\left(1-\frac{T_{a m b}}{T}\right)}{\int_{\text {Tamb }}^{T o u t} c d T}\right)=\dot{Q}_{c o g} \cdot\left(1-\frac{T_{a m b}}{T_{L M T D}}\right)
$$

The ideal efficiency is evaluated with reference to the Lorentz cycle, because the heat produced by the micro-CHP system is available at variable temperature rather than at constant temperature.

The second law efficiency is calculated as follows:

$$
E x_{t o t}=\frac{P_{n e t . A C}+E x_{t h}}{\dot{m}_{f u e l} \cdot E x_{f u e l}}
$$

Starting from the measured performance of the fuel stack prototype (see Section 2.5) and the membrane reactor characteristics (see Section 3.3) measured in the project, the m-CHP system layout was optimised for integrating the membrane reactor and the PEM FC stack. The optimization took into account both efficiency and cost aspects: in particular, the membrane surface area was monitored in the optimization being the component with the largest variation.

Two different membrane reactors lay-outs were investigated: the main difference being the adoption of a sweep flow at the permeate side to reduce the membrane surface area instead of a vacuum pump. For both cases, several design parameters of the membrane reactor (i.e., temperature, $\mathrm{S} / \mathrm{C}$ ratio, feed, and permeate pressures) as well as other components (i.e., fuel cell current density, burner temperature, etc.) were considered.

The net electric efficiency as a function of the membrane surface area and diverse reactor configuration and operating conditions is plotted in Figure 26. In general, the higher the membrane 
area, the higher is the electrical efficiency. A high S/C ratio penalizes the system from the electrical efficiency perspective, while reducing the membrane surface area thanks to the higher hydrogen partial pressure.

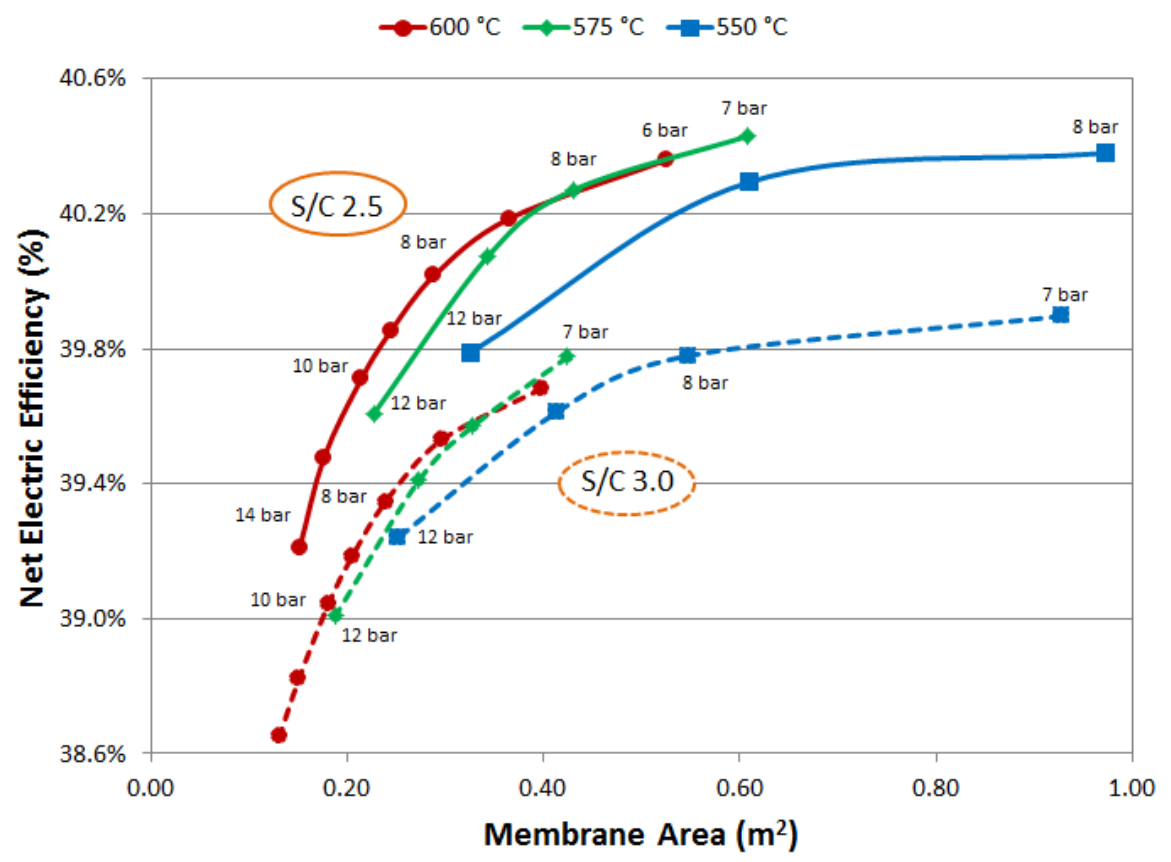

Figure 26. Sweep gas case: electrical efficiency versus membrane area at diverse reforming temperature, pressures and S/C ratios. Reproduced with permission from [26] Copyright, 2015, Elsevier.

The reactor temperature has the most significant impact on the membrane surface area for both higher hydrogen partial pressure and membrane permeance. Finally, the vacuum pump configuration shows even lower electric efficiency because of the pump consumption. Further details on this analysis can be found in [26]. It can be noted that the maximum electric efficiency is about $40.5 \%$. Even higher efficiency can be achieved by increasing the fuel cell conversion efficiency (i.e., reducing the current density), but this option is not worth it economically wise, because the additional cost of the fuel cell would not be balanced.

The main results of the simulation for the most representative cases are summarized in Table 5, two cases for the layout with sweep cases and for the layout with vacuum pump. Results can be compared with the traditional cases (SR and ATR) where net electrical and thermal efficiencies are in the range of $33 \%$ and $50 \%$ respectively. In terms of energy efficiency, all the proposed cases are above $41 \%$, with maximum at $43.77 \%$ which is $6 \%$ points higher than the reference case with steam reforming.

The application of the ReforCELL concept to biogas as fuel feeding was also investigated. The main difference between natural gas and biogas is in the concentration of the methane: in biogas it is about half of an average European natural gas composition. Two different biogas compositions were considered and evaluated: a typical landfill $\left(\mathrm{CH}_{4} 44.2 \%, \mathrm{CO}_{2} 34 \%\right.$, and $\left.\mathrm{LHV} 12.7 \mathrm{MJ} / \mathrm{kg}\right)$ and an anaerobic digester $\left(\mathrm{CH}_{4} 58.0 \%, \mathrm{CO}_{2} 34.0 \%\right.$, and LHV $\left.17.8 \mathrm{MJ} / \mathrm{kg}\right)$ compositions.

The efficiency variation for the three different considered fuel compositions and assuming vacuum pump lay-out as a function of membrane area is shown in Figure 27. 
Table 5. Performances of ReforCELL cases. Reproduced with permission from [26] Copyright, 2015, Elsevier.

\begin{tabular}{cccccc}
\hline Results & Units & \multicolumn{2}{c}{ Sweep Case } & \multicolumn{2}{c}{ Vacuum Pump } \\
\hline S/C & - & 2.5 & 3 & 2.5 & 3 \\
Pressure reaction side & $\mathrm{bar}$ & 8 & 8 & 8 & 8 \\
Pressure permeate side & $\mathrm{bar}$ & 1.2 & 1.2 & 0.3 & 0.3 \\
NG power input (LHV base) & $\mathrm{kW}$ & 12.50 & 12.71 & 13.22 & 13.05 \\
NG power input (HHV base) & $\mathrm{kW}$ & 13.84 & 14.08 & 14.64 & 14.46 \\
Net AC power output & $\mathrm{kW}$ & 5.00 & 5.00 & 5.00 & 5.00 \\
Fuel Cell AC power output & $\mathrm{kW}$ & 6.31 & 6.32 & 6.64 & 6.63 \\
NG compressor & $\mathrm{kW}$ & 0.15 & 0.15 & 0.16 & 0.15 \\
Air compressor & $\mathrm{kW}$ & 0.35 & 0.35 & 0.37 & 0.37 \\
Cathode air blower & $\mathrm{kW}$ & 0.18 & 0.19 & 0.20 & 0.19 \\
Vacuum pump & $\mathrm{kW}$ & - & - & 0.27 & 0.27 \\
Balance of plant & $\mathrm{kW}$ & 0.64 & 0.62 & 0.65 & 0.65 \\
Thermal recovery & $\mathrm{kW}$ & 6.49 & 6.72 & 6.93 & 6.77 \\
Net electric efficiency (LHV base) & $\%_{\mathrm{LHV}}$ & 40.02 & 39.35 & 37.85 & 38.32 \\
Net electric efficiency (HHV base) & $\%_{\mathrm{HHV}}$ & 36.13 & 35.52 & 34.16 & 34.59 \\
Net thermal efficiency & $\%_{\mathrm{LHV}}$ & 51.97 & 52.87 & 52.45 & 51.86 \\
Overall efficiency (LHV base) & $\%_{\mathrm{LHV}}$ & 91.99 & 92.22 & 90.30 & 90.18 \\
Overall efficiency (HHV base) & $\%_{\mathrm{HHV}}$ & 83.05 & 83.26 & 81.52 & 81.41 \\
Second law efficiency (Exergy base) & $\%_{\mathrm{Ex}}$ & 43.77 & 43.22 & 41.74 & 42.13 \\
Total membrane area & $\mathrm{m}{ }^{2}$ & 0.29 & 0.24 & 0.21 & 0.19 \\
\hline
\end{tabular}

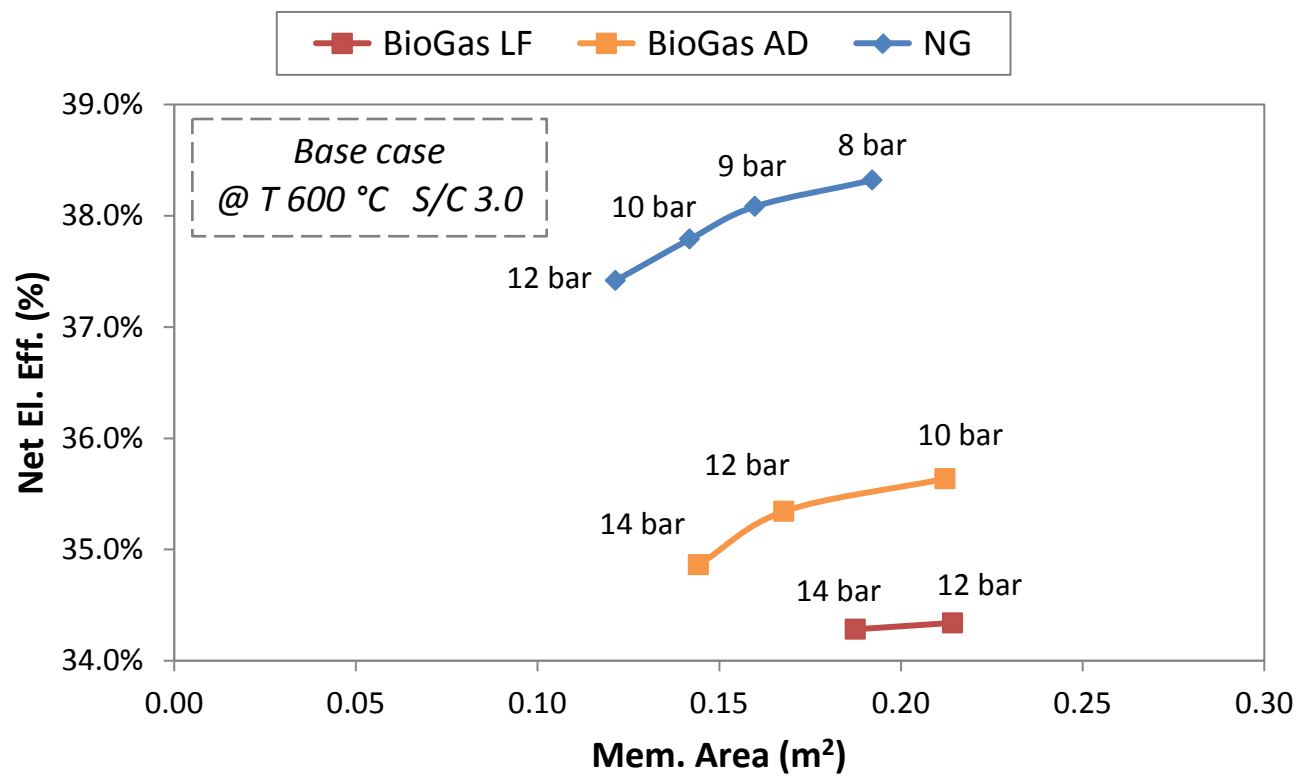

Figure 27. Efficiency vs. Membrane area for three different natural gasses assuming the ReforCELL concept.

An important result concerns the flexibility of the system with respect to the fuel composition. The membrane reactor can handle and separate pure hydrogen even from diluted methane as in biogas. Biogas requires higher membrane reactor pressures and membrane surface areas because of the methane dilution, which reduces the hydrogen partial pressure and consequently the permeation driving force. In the case of the vacuum pump the efficiency penalty is between $3 \%$ and $4 \%$, while it reduces to $1 \%$ for the sweep case. The net electrical efficiency with the same reactor design of NG case ranges from $34 \%$ to $39 \%$. Energy penalties in the flexible conversion system dealing with different natural gas also occur in commercial systems (i.e., the internal combustion reciprocating engine). 
Based on the optimized system layout fed with NG, BoP components were investigated. The selection and design of components and of the full system were carried out taking into account the compatibility of the main magnitudes (pressure, temperature etc.) and materials in the system, as well as costs. To manage the CHP system, a PLC is used. It is composed of two identical controllers (IOBLOCK): one communicates with the fuel processor PLC, and the other is used to measure each single cell voltage. Interface components (mechanical and electrical interface) and the system control strategy were also defined. However, the final integration and test of the system was not finalized due to liquidation of the company in charge of testing near the end of the project.

On the other side, system size scale up was also assessed, investigating the three main components of the CHP system (ATR, fuel cell stack, balance of plant); technical feasibility and economical aspects were taken into account. The maximum size considered is $50 \mathrm{kWe}$ according to European Directive 2012/27/EU on energy efficiency.

Once technical feasibility for sizes up to $50 \mathrm{kWe}$ was verified, the final specific cost $(€ / \mathrm{kW})$ of the whole system was evaluated. The best size should be a system suited to supply $50 \mathrm{kWe}$. The specific cost decrease $(€ / \mathrm{kW})$ of the whole system liken to size increase is around $78 \%$.

Furthermore the flexibility of the CHP system scaled-up was evaluated, confirming the feasibility of partial load operations (as the system developed within the project) ensuring load decrease until 40\%.

Finally, the aspect of which size is more marketable across Europe was assessed: it is preferable to have small size systems (10-20 kWe) for the smallest buildings with a few dwellings, ensuring bigger sizes (30-50 kWe) with a modular approach.

\subsection{Life Cycle Assessment and Safety Analysis}

The polymer electrolyte membrane fuel cell (PEMFC) micro combined heat and power (m-CHP) system investigated in the ReforCELL project was assessed by means of a life cycle assessment (LCA), a method standardized by the International Organisation for Standardization (ISO) 14040-44 standards $[78,79]$. The general objective was to perform a LCA which evaluates the environmental burdens of conventional PEMFC m-CHP systems (both steam methane reforming (SMR) and autothermal reforming (ATR)) over their whole life cycle ("cradle to grave") and to compare them with the developed ReforCELL technology system. The type of use considered is the production of heat and electricity for several dwellings. To have also an idea of the position of the PEMFC m-CHP systems in comparison with other technologies, their impact was also compared with the impact of a natural gas conventional $\mathrm{CHP}$, an alternative where electricity and heat come from the average mix (European electricity mix and country average heat mix) and a last one where electricity and heat come from a green available technology (called "GAT", wind power and solar thermal). Finally, there were six systems compared in the detailed LCA:

- Fuel cell micro-CHP conventional system with steam methane reforming (SMR)

- Fuel cell micro-CHP conventional system with autothermal reforming (ATR)

- Fuel cell micro-CHP ReforCELL developed technology: autothermal reforming with membrane reformer (ATR MR)

- $\quad$ Natural gas fuelled CHP system (50 kWe)

- System without CHP conventional (using electricity from the grid and an average heat mix)

- System without CHP green available technology (using wind power and solar thermal)

The LCA was performed using the ecoinvent v2.2 life cycle inventory database [80] and the life cycle impact assessment method IMPACT 2002+ [81,82]. The indicators assessed are climate change, resources consumption, impact on human health and on ecosystem quality and water withdrawal. The systems studied include the CHP production, its maintenance and its end-of-life treatment, the natural gas input, the direct emissions during use, the auxiliary boiler (including its production, end-of-life and use, i.e., natural gas production and combustion), the purchased heat (for the systems without (HP) and purchased electricity as described in Figure 28. 


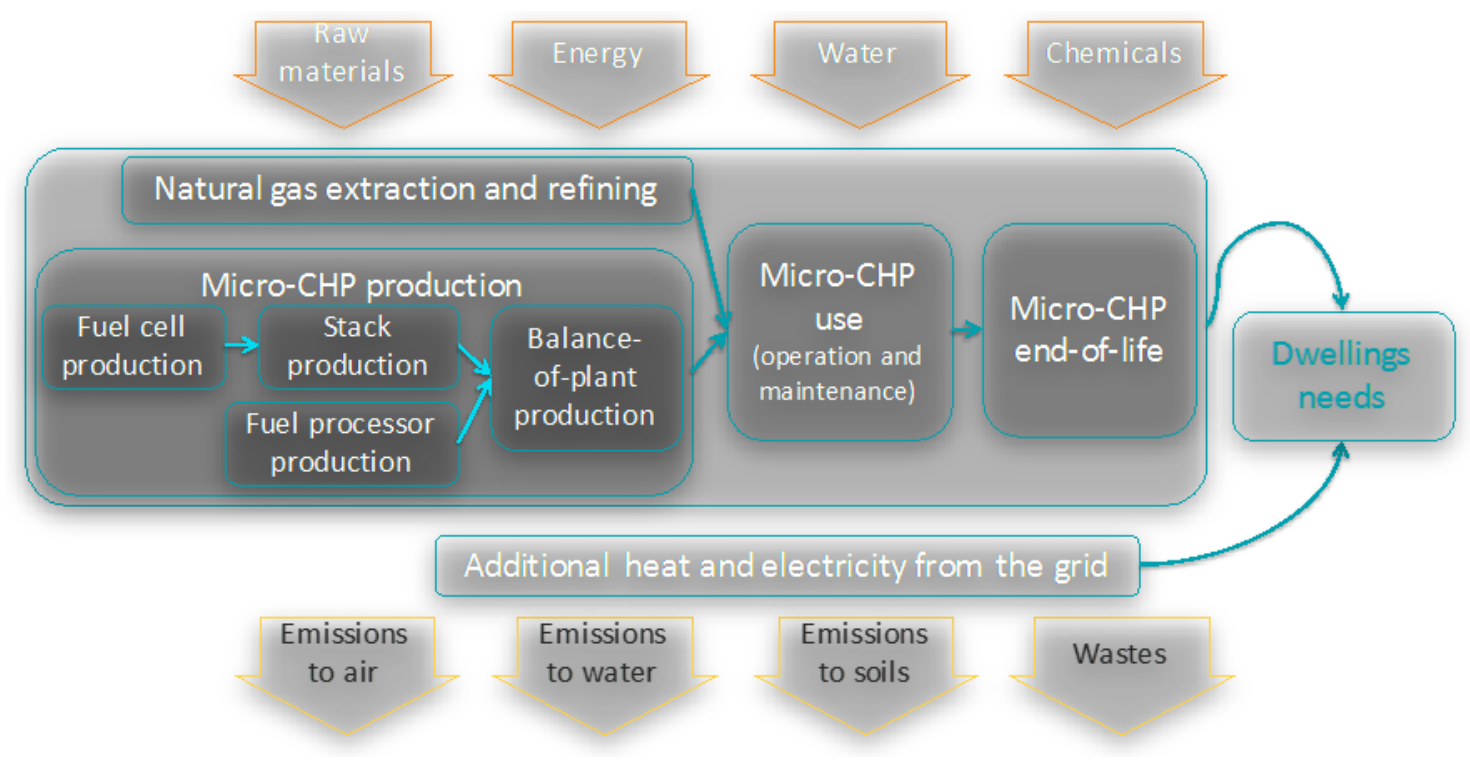

Figure 28. System boundaries for the PEMFC m-CHP LCA.

Figure 29 shows that the main contributors to the impacts of the ReforCELL system are extraction and distribution of the natural gas (especially for resources consumption), the direct emissions from reforming (regarding climate change), the auxiliary boiler and the purchased electricity. The m-CHP production, maintenance and end-of-life are very low contributors to the impacts, except for human health. The ReforCELL developed technology has lower impacts than the conventional production of electricity and heat, but higher impacts than a theoretical optimistic case where wind power and solar thermal are used.

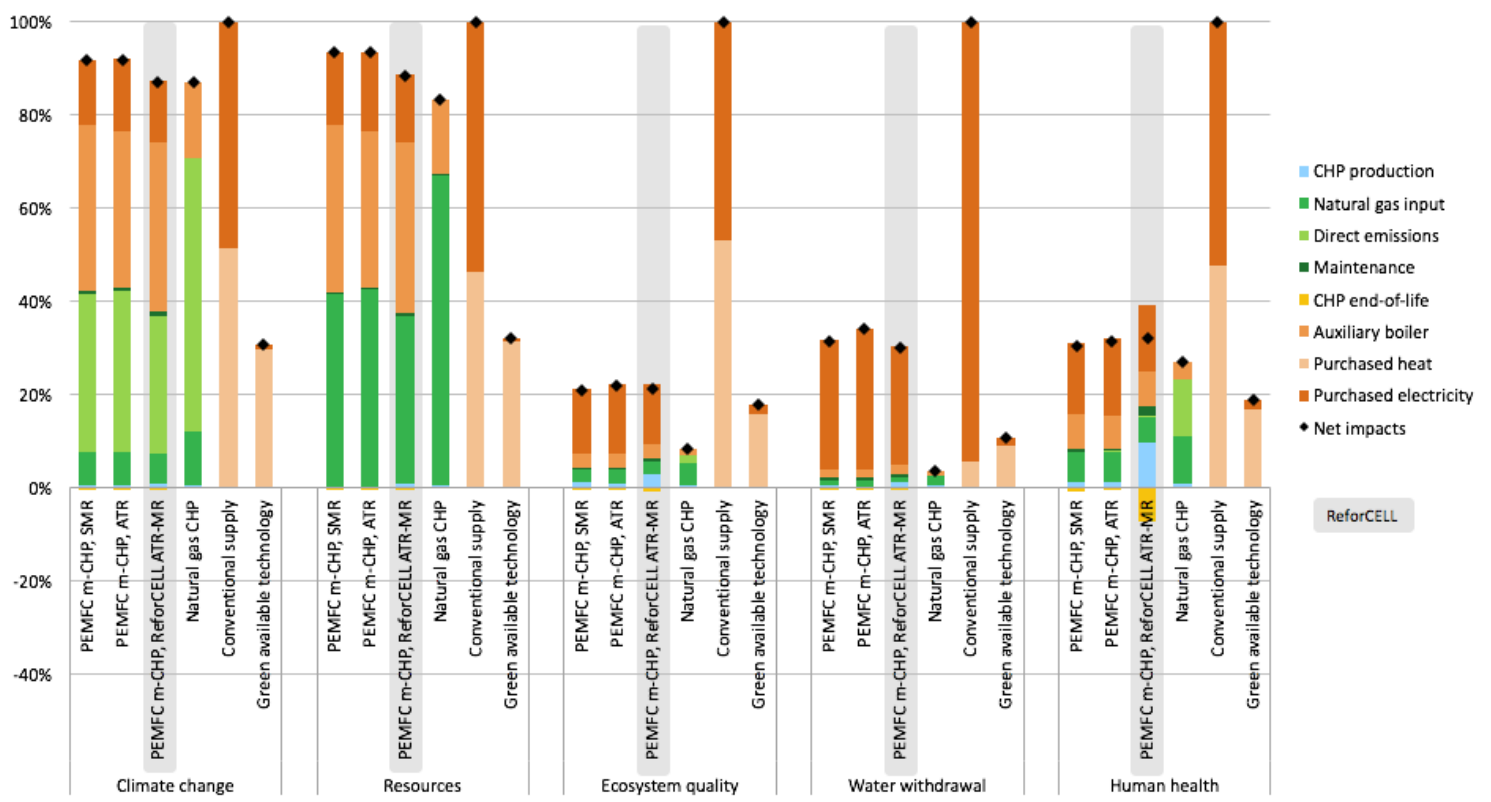

Figure 29. Environmental impact comparison of various alternatives assessed for the Italian market. Results for the yearly consumption of 14 dwellings. PEMFC m-CHP SMR and ATR correspond to the standard PEMFC systems. PEMFC m-CHP ReforCELL ATR-MR is the alternative developed through the ReforCELL project. 
Among PEMFC m-CHP systems, the ReforCELL developed technology has slightly lower impacts than the others for climate change and resources consumption while they all have similar impacts for the other indicators considered (slight differences are visible but due to the uncertainty on these indicators, they cannot be considered as different). The large natural gas CHP has a lower impact than the m-CHPs systems assessed but it is not destined to provide a small-scale local supply as the PEMFC m-CHP systems are. These results were obtained for the Italian market, for scenarios where excess electricity can be injected on the grid but not sold and with a dimensioning for 14 dwellings. The exercise has been done for the German market, leading to similar conclusions. Scenarios where the electricity could be sold at a good price (up to $70 \%$ of the purchasing price) were also assessed and they lead to a slight reduction of the impacts compared to the score presented above. A sensitivity analysis on the dimensioning would give different conclusions: if the CHP system is dimensioned to fulfil a higher fraction of the needs in heat and the surplus electricity is injected to the grid, the results become better. Indeed, injecting electricity to the grid enables conventional electricity production to be avoided and represents a benefit. Other sensitivity analyses were performed on the electricity mix choice, the electric efficiency of the ReforCELL system, the energy use for manufacturing, the treatment of the ReforCELL m-CHP at the end-of-life or the type of heat considered for the conventional supply but they do not show a big influence on the conclusions, or at least not for all indicators. Normalized and weighted results show the importance of climate change and resources indicators for systems such as those studied.

Regarding safety analysis, HyGear identified and evaluated specific safety reactor/membrane parameters for the membrane reactor using tools such as HAZOP and heat and mass transfer transport reaction models, whereas ICI identified and evaluated the safety parameters on the complete system.

\section{Conclusions}

The ReforCELL project aimed at the development of high efficient PEM fuel cell micro Combined Heat and Power cogeneration systems based on a novel hydrogen membrane reforming unit together with a new design of the subcomponent for the BoP.

The approach for the development involved the whole product chain: development of active catalysts and membranes for $\mathrm{H}_{2}$ permeation were investigated. Stability over time and mechanical resistance were the two main characteristics aimed for in this project. Subsequently, the interaction between the catalyst and the membranes, and the performance of the reactor concept were proven at lab-scale when combining both at reactive conditions in two different layouts: micro-channel reactor and fluidized bed membrane reactor. Afterward, and following HAZOP procedures, the fluidized bed membrane reactor was scaled up to prototype scale.

In parallel, modelling and testing activities enabled the investigation of the fuel cell system and operating conditions; a new PEM fuel cell stack was designed and a new configuration of the optimized m-CHP system was defined for the targeted application. Additionally, assessment of environmental, health and safety issues in relation to the new intensified chemical processes and m-CHP was carried out.

The Ru based catalyst, supported on Ceria/Zirconia, showed good activity and long-term stability at lower temperature $\left(500-600^{\circ} \mathrm{C}\right)$ compared to the Ni based commercial catalyst in use at a high temperature $\left(800^{\circ} \mathrm{C}\right)$. Moreover the fluidization regime allowed the prevention of the formation of hot spots thus increasing its lifetime.

Three different types of membranes were improved within the project: Pd-based tubular ceramic supported membranes, Pd-based tubular metallic supported membranes, and Pd-based micro-channel supported membranes. Stability of the membranes was confirmed through single gas permeation tests at operating temperatures over several days without any decrease in the membrane performance. Furthermore, new sealing methods for the tubular membranes were tested and proposed in order to fix the membranes inside the membrane reactors. Permeances and selectivities obtained with the 
different membranes are among the best ever reported in the literature and well above the targets for the ReforCELL project.

Both reactor configurations (micro-channel reactor and fluidized bed membrane reactor were validated at lab-scale under SMR and/or ATR. However, the process should be performed at lower temperatures than expected $\left(<550^{\circ} \mathrm{C}\right)$ to improve long term stability of the membranes. Fluidized bed membrane reactor configuration was selected for the prototype reactor. Difficulties were found related to the fragility of the ceramic supports of the membranes which failed early in the testing phase. An improved protocol for handling, assembling and testing the membranes was defined for further developments to reduce this risk.

A Fuel Cell stack prototype was manufactured and validated and an optimized m-CHP system layout defined. Based on the optimized system layout fed with NG, BoP components were investigated. The selection and design of components and of the full system was carried out taking into account the compatibility of main magnitudes (pressure, temperature, etc.) and materials in the system, as well as costs. However, the final integration and test was not finalized due to liquidation of the company in charge of the full system testing in the frame of the project. The simulations assessed that the net electric and overall efficiency of the Reforcell concept when using NG as fuel can be higher than $40 \%$ and $90 \%$ respectively. Biogas can also be adopted to feed the membrane reactor with penalties in terms of net electric efficiency due to the presence of $\mathrm{CO}_{2}$ and inerts in the biogas which dilutes the hydrogen.

According to the results obtained in the ReforCELL project, the m-CHP system could not yet be considered at prototype level. Much effort is still required to improve the standard sealing methods and durability of the membranes at high temperature in a cost effective way.

Acknowledgments: The research leading to these results has received funding from the European Union's Seventh Framework Programme (FP7/2007-2013) for the Fuel Cells and Hydrogen Joint Technology Initiative under grant agreement $n^{\circ} 278997$ (ReforCELL project).
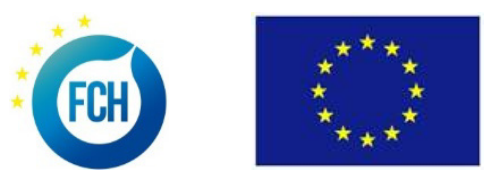

Disclaimer: The present publication reflects only the author's views and the FCH JU and the Union are not liable for any use that may be made of the information contained therein.

Author Contributions: All authors contributed to writing and correcting the paper. José Luis Viviente was the Project Coordinator and contributed to the development of Pd-based membranes onto tubular supports, Sylvie Escribano contributed to all the steps concerning the fuel cell, Giampaolo Manzolini was the Dissemination Manager and contributed to the design and optimization of the m-CHP system, Marit Stange developed Pd-based membranes for the micro-channel reactor and validated this reactor at lab-scale, Carlo Tregambe contributed to the optimization of the m-CHP system, Leonardo Roses was the Exploitation Manager and designed, build and tested the membrane reactor prototype, Arjan J. J. Koekkoek developed the catalyst, Cécile Guignard and Arnaud Dauriat performed the Life Cycle Analysis and Fausto Gallucci was the Technical Manager and contributed to the membranes characterization as well as designing, building and validating the fluidized bed membrane reactor at lab-scale.

Conflicts of Interest: The authors declare no conflict of interest.

\section{Abbreviations}

The following abbreviations are used in this manuscript:

$\begin{array}{ll}\text { ATEX } & \text { Appareils destinés à être utilisés en ATmosphères EXplosibles } \\ \text { ATR } & \text { Autothermal reformer } \\ \text { ATR-MR } & \text { Autothermal membrane reformer } \\ \text { BET } & \text { Brunauer-Emmett-Teller } \\ \text { BoP } & \text { Balance of plant } \\ \text { BIC } & \text { Boreskov Institute of Catalysis } \\ \text { CAPEX } & \text { Capital expenditure } \\ \text { CEM } & \text { Controlled evaporation and mixer } \\ \text { CHP } & \text { Combined heat and power }\end{array}$




\begin{tabular}{|c|c|}
\hline CMP & Compressor \\
\hline ELP & Electroless plating \\
\hline FBR & Fluidized bed reactor \\
\hline FBMR & Fluidized bed membrane reactor \\
\hline FC & Fuel cell \\
\hline FP7 & Seventh Framework Programme \\
\hline GAT & Green available technology \\
\hline GHSV & gas hourly space velocity \\
\hline HAZOP & Hazard and operability study \\
\hline HHV & High heating value \\
\hline HRF & $\mathrm{H}_{2}$ recovery factor \\
\hline HSF & $\mathrm{H}_{2}$ separation factor \\
\hline HT-WGS & High temperature water gas shift \\
\hline HX & heat exchanger \\
\hline ICP-OES & Inductively coupled plasma optical emission spectrometry \\
\hline ID & Inside diameter \\
\hline IMDBL & Inter-metallic diffusion barrier layer \\
\hline $\mathrm{kW}$ & kilowatt \\
\hline LCA & Life cycle assessment \\
\hline LHV & Low heating value \\
\hline LT-WGS & Low temperature water gas shift \\
\hline $\mathrm{m}-\mathrm{CHP}$ & micro combined heat and power \\
\hline MR & membrane reactor \\
\hline $\mathrm{N} / \mathrm{C}$ & Nitrogen-to-Carbon ratio \\
\hline NG & Natural gas \\
\hline $\mathrm{O} / \mathrm{C}$ & Oxigen-to-carbon ratio \\
\hline OD & outside diameter \\
\hline PEM & Polymer electrolyte membrane type \\
\hline PEMFC & Polymer electrolyte membrane fuel cell \\
\hline PEM m-CHP & Polymer electrolyte membrane fuel cell micro combined heat and power \\
\hline PFD & Process flow diagram \\
\hline PLC & Programmable logic controller \\
\hline PROX & Preferential oxidizer \\
\hline PSS & Porous stainless steel \\
\hline SMR & steam methane reforming \\
\hline $\mathrm{S} / \mathrm{C}$ & Steam-to-Carbon ratio \\
\hline TEM & Transmission electron microscopy \\
\hline TPO & Temperature programmed oxidation \\
\hline TRL & Technology Readiness Level \\
\hline $\mathrm{u}$ & fluidization velocity \\
\hline $\mathrm{u}_{\mathrm{mf}}$ & minimum fluidization velocity \\
\hline WGS & Water gas shift \\
\hline W/F ratio & Weight to feed ratio \\
\hline XPS & X-ray photoelectron spectroscopy \\
\hline XRD & X-ray diffraction \\
\hline YSZ & Yttria-stabilized zirconia \\
\hline
\end{tabular}

\section{References}

1. European Commission. A Policy Framework for Climate and Energy in the Period from 2020 to 2030 (COM(2014) 15). Available online: https://ec.europa.eu/energy/en/topics/energy-strategy/2030-energystrategy (accessed on 31 March 2016).

2. Advancing Europe's Energy System: Stationary Fuel Cell in Distributed Generation; FCH JU, Luxemburg Publications Office of the European Union: Luxemburg City, Luxemburg, 2015. Available online: http:/ / www.fch.europa.eu/studies (accessed on 31 March 2016).

3. Alanne, K.; Saari, A. Sustainable small-scale CHP technologies for buildings: The basis for multi-perspective decision-making. Renew. Sustain. Energy Rev. 2004, 8, 401-431. [CrossRef]

4. Campanari, S.; Macchi, E.; Manzolini, G. Membrane reformer PEM cogeneration systems for residential applications-Part B: Techno-economic analysis and system layout. Asia Pac. J. Chem. Eng. 2009, 4, 311-321. [CrossRef]

5. Elmer, T.; Worall, M.; Wu, S.; Riffat, S.B. Fuel cell technology for domestic built environment applications: State of-the-art review. Renew. Sustain. Energy Rev. 2015, 42, 913-931. [CrossRef] 
6. Dodds, P.E.; Staffell, I.; Hawkes, A.D.; Li, F.; Grünewald, P.; McDowall, W. Hydrogen and fuel cell technologies for heating: A review. Int. J. Hydrog. Energy 2015, 40, 2065-2083. [CrossRef]

7. International Energy Agency. Key World Energy Statistics, OECD/IEA. 2015. Available online: https://www.iea.org/publications/freepublications/publication/KeyWorld_Statistics_2015.pdf (accessed on 31 March 2016).

8. Dorer, V.; Weber, R.; Weber, A. Performance assessment of fuel cell micro-cogeneration systems for residential buildings. Energy Build. 2005, 37, 1132-1146. [CrossRef]

9. International Energy Agency. Medium-Term Renewable Energy Market Report 2014: Market Analysis and Forecast to 2020, OECD/IEA. 2014. Available online: http:/ /www.iea.org/publications / freepublications / publication/medium-term-renewable-energy-market-report-2014.html (accessed on 31 March 2016).

10. Reay, D.; Ramshaw, C.; Harvey, A. Process Intensification; Elsevier: Oxford, UK, 2008.

11. Gallucci, F.; Fernandez, E.; Corengia, P.; van Sint Annaland, M. Recent advances on membranes and membrane reactors for hydrogen production. Chem. Eng. Sci. 2013, 92, 40-66. [CrossRef]

12. Palladium Membrane Technology for Hydrogen Production, Carbon Capture and Other Applications, 1st ed.; Doukelis, A.; Panopoulos, K.; Koumanakos, A.; Kakaras, E., Eds.; Woodhead Publishing: Amsterdam, The Netherlands, 2015.

13. Gallucci, F.; Comite, A.; Capannelli, G.; Basile, A. Steam Reforming of Methane in a Membrane Reactor: An Industrial Case Study. Ind. Eng. Chem. Res. 2006, 45, 2994-3000. [CrossRef]

14. Matsumura, Y.; Tong, J. Methane Steam Reforming in Hydrogen-permeable Membrane Reactor for Pure Hydrogen Production. Top. Catal. 2008, 51, 123-132. [CrossRef]

15. Yakabe, H.; Kurokawa, H.; Shirasaki, Y.; Yasuda, I. Operation of palladium membrane reformer system for hydrogen production: The case of Tokio Gas. In Palladium Membrane Technology Hydrogen Production Carbon Capture Other Applications; Woodhead Publishing: Amsterdam, The Netherlands, 2015; p. 311.

16. Deshmukh, S.A.R.K.; Heinrich, S.; Mörl, L.; van Sint Annaland, M.; Kuipers, J.A.M. Membrane assisted fluidized bed reactors: Potentials and hurdles. Chem. Eng. Sci. 2007, 62, 416-436. [CrossRef]

17. Brunetti, A.; Drioli, E.; Barbieri, G. Energy and mass intensities in hydrogen upgrading by a membrane reactor. Fuel Process. Technol. 2014, 118, 278-286. [CrossRef]

18. Barbieri, G.; Brunetti, A.; Caravella, A.; Drioli, E. Pd-based membrane reactors for one-stage process of water gas shift. RSC Adv. 2011, 1, 651-661. [CrossRef]

19. Roses, L.; Gallucci, F.; Manzolini, G.; Campanari, S.; van Sint Annaland, M. Comparison between fixed bed and fluidized bed membrane reactor configurations for PEM based micro-cogeneration systems. Chem. Eng. J. 2011, 171, 1415-1427. [CrossRef]

20. Campanari, S.; Macchi, E.; Manzolini, G. Innovative membrane reformer for hydrogen production applied to PEM micro-cogeneration: Simulation model and thermodynamic analysis. Int. J. Hydrog. Energy 2008, 33, 1361-1373. [CrossRef]

21. Mathiak, J.; Heinzel, A.; Roes, J.; Kalk, T.; Kraus, H.; Brandt, H. Coupling of a $2.5 \mathrm{~kW}$ steam reformer with a 1 kWel PEM fuel cell. J. Power Sources 2004, 131, 112-119. [CrossRef]

22. Gandiglio, M.; Lanzini, A.; Santarelli, M.; Leone, P. Design and optimization of a proton exchange membrane fuel cell CHP system for residential use. Energy Build. 2014, 69, 381-393. [CrossRef]

23. Xie, D.; Wang, Z.; Jin, L.; Zhang, Y. Energy and exergy analysis of a fuel cell based micro combined heat and power cogeneration system. Energy Build. 2012, 50, 266-272. [CrossRef]

24. Gigliucci, G.; Petruzzi, L.; Cerelli, E.; Garzisi, A.; La Mendola, A. Demonstration of a residential CHP system based on PEM fuel cells. J. Power Sources 2004, 131, 62-68. [CrossRef]

25. Seo, Y.T.; Seo, D.J.; Jeong, J.H.; Yoon, W.L. Development of compact fuel processor for $2 \mathrm{~kW}$ class residential PEMFCs. J. Power Sources 2006, 163, 119-124. [CrossRef]

26. Di Marcoberardino, G.; Roses, L.; Manzolini, G. Technical assessment of a micro-cogeneration system based on polymer electrolyte membrane fuel cell and fluidized bed autothermal reformer. Appl. Energy 2016, 162, 231-244. [CrossRef]

27. Nuvera. Avanti ${ }^{\circledR}$ Fuel Cell Power System. 2010. Available online: https://www.hydrogen.energy.gov/pdfs / htac_may2012_nuvera.pdf (accessed on 12 September 2016).

28. Nishizaki, K.; Tokyo Gas Co. The Japanese Experience in Micro CHP for Residential Use, Gas Industry Micro CHP Workshop, Macrogaz. 2008. Available online: http://www.marcogaz.org/index.php/workshops/ micro-chp-ws (accessed on 12 September 2016). 
29. FuelCell Energy. Combined Heat \& Power. Available online: http://www.fuelcellenergy.com/why-fuelcellenergy/benefits/combined-heat-power-chp/ (accessed on 12 September 2016).

30. Campanari, S.; Macchi, E.; Manzolini, G. Membrane reformer PEM cogeneration systems for residential applications-Part A: full load and partial load simulation. Asia Pac. J. Chem. Eng. 2009, 4, 301-310. [CrossRef]

31. Aasberg-Petersen, K.; Dybkjær, I.; Ovesen, C.V.; Schjødt, N.C.; Sehested, J.; Thomsen, S.G. Natural gas to synthesis gas-Catalysts and catalytic processes. J. Nat. Gas Sci. Eng. 2011, 3, 423-459. [CrossRef]

32. Horn, R.; Schlögl, R. Methane Activation by Heterogeneous Catalysis. Catal. Lett. 2015, 145, 23-39. [CrossRef]

33. Erri, P.; Dinka, P.; Varma, A. Novel perovskite-based catalysts for autothermal JP-8 fuel reforming. Chem. Eng. Sci. 2006, 61, 5328-5333. [CrossRef]

34. Liu, D.; Krumpelt, M. Activity and Structure of Perovskites as Diesel-Reforming Catalysts for Solid Oxide Fuel Cell. Int. J. Appl. Ceram. Technol. 2005, 2, 301-307. [CrossRef]

35. Mawdsley, J.R.; Krause, T.R. Rare earth-first-row transition metal perovskites as catalysts for the autothermal reforming of hydrocarbon fuels to generate hydrogen. Appl. Catal. A 2008, 334, 311-320. [CrossRef]

36. Devi, R.N.; Chilukuri, S.V.V. CeAlO3 Perovskites Containing Transition Metal Perovskites Containing Transition Metal for Hydrogen Production. US 20120264597 A1, 18 October 2012.

37. Cheekatamarla, P.K.; Thomson, W.J. Hydrogen generation from 2,2,4-trimethyl pentane reforming over molybdenum carbide at low steam-to-carbon ratios. J. Power Sources 2006, 156, 520-524. [CrossRef]

38. Ismagilov, Z.R.; Kuntsevich, S.V.; Kuznetsov, V.V.; Shikina, N.V.; Kerzhentsev, M.A.; Rogov, V.A.; Ushakov, V.A. Characterization of new catalysts based on uranium oxides. Kinet. Catal. 2007, 48, 511-520. [CrossRef]

39. Tada, M.; Zhang, S.H.; Malwadkar, S.; Ishiguro, N.; Soga, J.; Nagai, Y.; Tezuka, K.; Imoto, H.; Otsuka-Yao-Matsuo, S.; Ohkoshi, S.; et al. The active phase of nickel/ordered $\mathrm{Ce}_{2} \mathrm{Zr}_{2} \mathrm{O}_{\mathrm{x}}$ catalysts with a discontinuity $(x=7-8)$ in methane steam reforming. Angew. Chem. 2012, 124, 9495-9499. [CrossRef]

40. Fang, X.; Zhang, X.; Guo, Y.; Chen, M.; Liu, W.; Xu, X.; Peng, H.; Gao, Z.; Wang, X.; Li, C. Highly active and stable $\mathrm{Ni} / \mathrm{Y}_{2} \mathrm{Zr}_{2} \mathrm{O}_{7}$ catalysts for methane steam reforming: On the nature and effective preparation method of the pyrochlore support. Int. J. Hydrog. Energy 2016, 41, 11141-11153. [CrossRef]

41. Ismagilov, Z.R.; Kuntsevich, S.V. Advanced uranium containing catalysts for methane reforming. In Proceedings of the NHA Annual Hydrogen Conference, San Antonio, TX, USA, 19-22 March 2007.

42. Kuznetsov, V.V.; Ismagilov, Z.R.; Shikina, N.V.; Lazarchuk, V.V.; Balakhonov, V.G.; Matyuha, V.A.; Drobyaz, A.I.; Khlytin, A.L. New uranium oxide catalysts for hydrogen production by partial oxidation and reforming of methane. In Proceedings of the International Conference "CATALYSIS: FUNDAMENTALS AND APPLICATION", Novosibirsk, Russia, 4-8 July 2007.

43. Ismagilov, Z.R.; Kuntsevich, S.V.; Kuznetsov, V.V.; Shikina, N.V. Advanced uranium containing catalysts for methane reforming. In Proceedings of the International Symposium on Catalysis Engineering, Delft, The Netherlands, 14 June 2007; pp. 63-64.

44. Barbier, J.; Corro, G.; Marecot, P.; Bournonville, J.P.; Frank, J.P. Structure sensitivity and coke formation on $\mathrm{Pt} / \mathrm{Al}_{2} \mathrm{O}_{3}$ catalysts. Reat. Kinet. Catal. Lett. 1985, 28, 245-250. [CrossRef]

45. Barbier, J. Catalyst Deactivation 1987. In Proceedings of the 4th International Symposium, Antwerp, Belgium, 29 September-1 October 1987; Delmon, B., Froment, G.F., Eds.; Elsevier: Amsterdam, The Netherlands, 1987.

46. Di Monte, R.; Kašpar, J. Nanostructured $\mathrm{CeO}_{2}-\mathrm{ZrO}_{2}$ mixed oxides. J. Mater. Chem. 2005, 15, 633-648. [CrossRef]

47. Guzman, J.; Carrettin, S.; Corma, A. Spectroscopic Evidence for the Supply of Reactive Oxygen during CO Oxidation Catalyzed by Gold Supported on Nanocrystalline $\mathrm{CeO}_{2}$. J. Am. Chem. Soc. 2005, 127, 3286-3287. [CrossRef] [PubMed]

48. Okazaki, J.; Ikeda, T.; Pacheco Tanaka, D.A.; Llosa Tanco, M.A.; Wakui, Y.; Sato, K.; Mizukami, F.; Suzuki, T.M. Strong Interaction at the Palladium/Alumina Interface of Membrane during Hydrogen Permeation at Elevated Temperature. Chem. Lett. 2008, 37, 1004-1005. [CrossRef]

49. Okazaki, J.; Ikeda, T.; Pacheco Tanaka, D.A.; Llosa Tanco, M.A.; Wakui, Y.; Sato, K.; Mizukami, F.; Suzuki, T.M. Importance of the support material in thin palladium composite membranes for steady hydrogen permeation at elevated temperatures. Phys. Chem. Chem. Phys. 2009, 11, 8632-8638. [CrossRef] [PubMed]

50. Okazaki, J.; Ikeda, T.; Pacheco Tanaka, D.A.; Sato, K.; Suzuki, T.M.; Mizukami, F. An investigation of thermal stability of thin palladium-silver alloy membranes for high temperature hydrogen separation. J. Membr. Sci. 2011, 366, 212-219. [CrossRef] 
51. Fernandez, E.; Coenen, K.; Helmi, A.; Melendez, J.; Zuñiga, J.; Tanaka, D.A.P.; van Sint Annaland, M.; Gallucci, F. Preparation and characterization of thin-film Pd-Ag supported membranes for high-temperature applications. Int. J. Hydrog. Energy 2015, 40, 13463-13478. [CrossRef]

52. Fernandez, E.; Medrano, J.A.; Melendez, J.; Parco, M.; Viviente, J.L.; van Sint Annaland, M.; Gallucci, F.; Pacheco Tanaka, D.A. Preparation and characterization of metallic supported thin Pd-Ag membranes for hydrogen separation. Chem. Eng. J. 2016, 305, 182-190. [CrossRef]

53. Medrano, J.A.; Fernandez, E.; Melendez, J.; Parco, M.; Tanaka, D.A.P.; van Sint Annaland, M.; Gallucci, F. Pd-based metallic supported membranes: High-temperature stability and fluidized bed reactor testing. Int. J. Hydrog. Energy 2016, 41, 8706-8718. [CrossRef]

54. Pacheco Tanaka, D.A.; Llosa Tanco, M.A.; Niwa, S.; Wakui, Y.; Mizukami, F.; Namba, T.; Suzuki, T.M. Preparation of palladium and silver alloy membrane on a porous $\alpha$-alumina tube via simultaneous electroless plating. J. Membr. Sci. 2005, 247, 21-27. [CrossRef]

55. Bredesen, R.; Klette, H. Method of Manufacturing Thin Metal Membrane. U.S. Patent 6,086,729, 2000.

56. Mejdell, A.L.; Peters, T.A.; Stange, M.; Venvik, H.J.; Bredesen, R. Performance and application of thin Pd-alloy hydrogen separation membranes in different configurations. J. Taiwan Inst. Chem. Eng. 2009, 40, 253-259. [CrossRef]

57. Peters, T.A.; Stange, M.; Sunding, M.F.; Bredesen, R. Stability investigation of micro-configured Pd-Ag membrane modules-Effect of operating temperature and pressure. Int. J. Hydrog. Energy 2015, 40, 3497-3505. [CrossRef]

58. Peters, T.A.; Stange, M.; Bredesen, M. On the high pressure performance of thin supported $\mathrm{Pd}-23 \% \mathrm{Ag}$ membranes-Evidence of ultrahigh hydrogen flux after air treatment. J. Membr. Sci. 2011, 378, $28-34$. [CrossRef]

59. Pacheco Tanaka, D.A.; Melendez, J.; Fernandez, E.; Helmi, A.; Gallucci, F.; Arias, P.L. Preparation and characterization of ultra-thin ( $<1$ micron) Pd-Ag membranes on porous alumina support (100 $\mathrm{nm}$ pore size). In Proceedings of the 12th International Conference on Catalysis in Membrane Reactors, Szczecin, Poland, 22-25 June 2015.

60. Vicinanza, N.; Svenum, I.-H.; Næss, L.N.; Peters, T.A.; Bredesen, R.; Borg, A.; Venvik, H.J. Thickness dependent effects of solubility and surface phenomena on the hydrogen transport properties of sputtered Pd77\%Ag23\% thin film membranes. J. Membr. Sci. 2015, 476, 602-608. [CrossRef]

61. Pacheco Tanaka, D.A.; Okazaki, J.; Llosa Tanco, M.A.; Suzuki, T.M. Fabrication of supported palladium alloy membranes using electroless plating techniques. In Palladium Membrane Technology for Hydrogen Production, Carbon Capture and Other Applications, 1st ed.; Doukelis, A., Panopoulos, K., Koumanakos, A., Kakaras, E., Eds.; Woodhead Publishing: Amsterdam, The Netherlands, 2015; pp. 83-99.

62. Shi, L.; Goldbach, A.; Xu, H. High-flux $\mathrm{H}_{2}$ separation membranes from $(\mathrm{Pd} / \mathrm{Au})$ n nanolayers. Int. J. Hydrog. Energy 2011, 36, 2281-2284. [CrossRef]

63. Damle, A.; Acquaviva, J. Membrane Reactor for Hydrogen Production. In Proceedings of the AlChE 2008 Annual Meeting, Philadelphia, PA, USA, 8-13 November 2008. Available online: http://www.pall.com/ pdfs/OEM-Media-Membranes-and-Materials/Hydrogen_Reactor_for_Hydrogen_Production.pdf (accessed on 12 September 2016).

64. Helmi, A.; Fernandez, E.; Melendez, J.; Pacheco Tanaka, D.A.; Gallucci, F.; van Sint Annaland, M. Fluidized Bed Membrane Reactors for Ultra Pure $\mathrm{H}_{2}$ Production-A Step forward towards Commercialization. Molecules 2016, 21, 376-394. [CrossRef] [PubMed]

65. Fernandez, E.; Helmi, A.; Coenen, K.; Melendez, J.; Viviente, J.L.; Pacheco Tanaka, D.A.; van Sint Annaland, M.; Gallucci, F. Development of thin Pd-Ag supported membranes for fluidized bed membrane reactors including WGS related gases. Int. J. Hydrog. Energy 2015, 40, 3506-3519. [CrossRef]

66. Media and Process Technology Inc. Available online: http://www.mediaandprocess.com/products/ products02.html (accessed on 12 September 2016).

67. Goldbach, A.; Bao, F.; Qi, C.; Bao, C.; Zhao, L.; Hao, C.; Jiang, C.; Xu, H. Evaluation of Pd composite membrane for pre-combustion $\mathrm{CO}_{2}$ capture. Int. J. Greenh. Gas Control 2015, 33, 69-76. [CrossRef]

68. Veenstra, P.; Iyer, M.; Nijmeijer, A.; Geuzebroek, F.; Moene, R.; Saukaitis, J. Integrated Approach to $\mathrm{CO}_{2}$ Capture: Fuel Gas Decarbonisation. Energy Procedia 2014, 63, 2054-2059. [CrossRef] 
69. Li, A.; Boyd, T.; Gulamhusein, A.; Mahecha-Botero, A.; Grace, J.; Lim, J.; Xu, N. Towards Industrial Applications: Membrane and Fluidized Bed Reactor Research at MRT and NORAM. In Proceedings of ECN Workshop on Pd-Membrane Technology Scale-Up, Petten, The Netherlands, 20-21 November 2014.

70. Hysep: ECN, Hydrogen Seperation Modules. Available online: http://www.hysep.com/fileadmin/hysep/ user/documents/B-09-010-hysep.pdf (accessed on 12 September 2016).

71. Dittmar, B.; Behrens, A.; Schödel, N.; Rüttinger, M.; Franco, T.; Straczewski, G.; Dittmeyer, R. Methane steam reforming operation and thermal stability of new porous metal supported tubular palladium composite membranes. Int. J. Hydrog. Energy 2013, 38, 8759-8771. [CrossRef]

72. Gallucci, F.; van Sint Annaland, M.; Kuipers, J.A.M. Autothermal Reforming of Methane with Integrated $\mathrm{CO}_{2}$ Capture in a Novel Fluidized Bed Membrane Reactor. Part 2 Comparison of Reactor Configurations. Top. Catal. 2008, 51, 146-157. [CrossRef]

73. Wang, Y.; Chen, K.S.; Mishler, J.S.; Cho, C.; Cordobes Adroher, X. A review of polymer electrolyte membrane fuel cells: Technology, applications, and needs on fundamental research. Appl. Energy 2011, 88, 981-1007. [CrossRef]

74. Koski, P.; Pérez, L.C.; Ihonen, J. Comparing Anode Gas Recirculation with Hydrogen Purge and Bleed in a Novel PEMFC Laboratory Test Cell Configuration. Fuel Cells 2015, 15, 494-504. [CrossRef]

75. Pérez, L.C.; Rajala, T.; Ihonen, J.; Koski, P.; Sousa, J.M.; Mendes, A. Development of a methodology to optimize the air bleed in PEMFC systems operating with low quality hydrogen. Int. J. Hydrog. Energy 2013, 38, 16286-16299. [CrossRef]

76. Chattot, R.; Escribano, S. Ageing studies of a PEM Fuel Cell stack developed for reformate fuel operation in $\mu \mathrm{CHP}$ units: Development of an accelerated degradation procedure. Int. J. Hydrog. Energy 2015, 40, 5367-5374. [CrossRef]

77. Kikuchi, E.; Uemiya, S.; Matsuda, T. Natural Gas Conversion; Elsevier: Amsterdam, The Netherlands, 1991; Volume 61.

78. ISO 14040. Environmental Management_Life Cycle Assessment_Principles and Framework; International Standard Organization: Geneva, Switzerland, 2006.

79. ISO 14044. Environmental Management_Life Cycle Assessment_Requirements and Guidelines; International Standard Organization: Geneva, Switzerland, 2006.

80. Ecoinvent. Ecoinvent Database v2.2. 2010. Available online: http://www.ecoinvent.ch (accessed on 12 September 2016).

81. Jolliet, O.; Margni, M.; Charles, R.; Humbert, S.; Payet, J.; Rebitzer, G.; Rosenbaum, R. Impact 2002+: A New Life Cycle Impact Assessment Methodology. Int. J. Life Cycle Assess. 2003, 8, 324-330. [CrossRef]

82. Humbert, S.; de Schryver, A.; Margni, M.; Jolliet, O. IMPACT 2002+ User Guide: Draft for Version 2.2; Quantis: Lausanne, Switzerland, 2012. Available contacting: sebastien.humbert@quantis-intl.com (accessed on 1 October 2016).

(C) 2016 by the authors; licensee MDPI, Basel, Switzerland. This article is an open access article distributed under the terms and conditions of the Creative Commons Attribution (CC-BY) license (http://creativecommons.org/licenses/by/4.0/). 